\title{
Analysis of Factors Influencing Plant-Microbe Combined Remediation of Soil Contaminated by Polycyclic Aromatic Hydrocarbons
}

\author{
Lei Zhao ${ }^{1}$, Cong Lyu ${ }^{1, * \mathbb{D}}$ and $\mathrm{Yu} \mathrm{Li}^{2, * \mathbb{D}}$ \\ 1 College of New Energy and Environment, Jilin University, Changchun 130012, China; slzhaolei1981@126.com \\ 2 MOE Key Laboratory of Resources and Environmental Systems Optimization, \\ North China Electric Power University, Beijing 102206, China \\ * Correspondence: lvcong@jlu.edu.cn (C.L.); liyuxx8@hotmail.com (Y.L.); Tel.: +86-10-6177-2836 (Y.L.)
}

Citation: Zhao, L.; Lyu, C.; Li, Y. Analysis of Factors Influencing

Plant-Microbe Combined

Remediation of Soil Contaminated by Polycyclic Aromatic Hydrocarbons. Sustainability 2021, 13, 10695. https:/ / doi.org/10.3390/su131910695

Academic Editor:

Konstantinos Dimos

Received: 23 July 2021

Accepted: 23 September 2021

Published: 26 September 2021

Publisher's Note: MDPI stays neutral with regard to jurisdictional claims in published maps and institutional affiliations.

Copyright: (c) 2021 by the authors. Licensee MDPI, Basel, Switzerland. This article is an open access article distributed under the terms and conditions of the Creative Commons Attribution (CC BY) license (https:// creativecommons.org/licenses/by/ $4.0 /)$.

\begin{abstract}
Polycyclic aromatic hydrocarbons (PAHs) are frequently detected in soil. Their biological toxicity and carcinogenic, teratogenic, and mutagenic effects pose a great threat to the ecological environment and human health. Firstly, the sources, physicochemical properties, and environmental hazards of PAHs are reviewed in this paper, and then their pollution status and different methods for their detection in soil are described in detail. The remediation technologies to treat pollution in the field and farmland are compared, and the technical status and factors influencing phytomicrobial remediation of PAHs in contaminated soil are evaluated in the most comprehensive way. The mechanisms of phytomicrobial remediation of PAHs-contaminated soil under different conditions are innovatively discussed. Additionally, the regulation mechanism of enzymes involved in plant and microbial degradation of PAHs in soils is studied. This is the first study on the regulation mechanism of degradation enzyme in a PAHs review. The aim of this paper is to review the pollution status, remediation technologies, mechanisms, and biodegradation actions of PAHs in soil. This review creatively provides reliable technical support for strengthening soil remediation and environmental management.
\end{abstract}

Keywords: PAHs; soil pollution; microbial remediation; phytoremediation; plant-microbe combined remediation; transformation mechanism

\section{Introduction}

\subsection{Research Background and Purpose of PAHs}

Petroleum is one of the most important energy sources for mankind. The global annual output of oil is as high as 2.2 billion tons, of which 1.75 billion tons are produced by terrestrial oil fields [1]. With the use of petroleum in the process of survey, production, storage and transportation, refining and processing, a large volume of petroleum accidentally flows into the soil due to accidental leakage, improper operation, etc., causing serious petroleum soil pollution and worsening the originally fragile natural environment [2]. Petroleum pollutants in the soil include normal alkanes, branched chain alkanes, aromatic hydrocarbons, alicyclic hydrocarbons, etc. Compared with other petroleum pollutants, polycyclic aromatic hydrocarbons (PAHs) are a class of refractory organic matter [3]. As a typical petroleum pollutant, PAHs have received extensive attention from governments and the scientific community [4]. Since the US Environmental Protection Agency listed 16 PAHs as "priority control pollutants" in 1976, the European Union, China, and other international organizations and countries have gradually listed PAHs as priority control and reduction organic pollutants [5]. Therefore, research on the enhanced degradation of PAHs is one of the key problems in solving petroleum soil pollution. Taking PAHs as an example, the purpose of this review is to conduct theoretical research on the combined effects of enhanced degradation of microorganisms and absorption of plants. In addition, 
we developed a targeted, efficient, fast, and low-cost plant-microorganism joint-enhanced soil-oil pollution remediation technology.

\subsection{Sources, Properties, and Hazards of PAHs}

\subsubsection{Sources of PAHs}

PAHs are organic compounds containing two or more benzene rings. There are various types of aromatic hydrocarbons recognized as semivolatile organic contaminants and thus have attracted attention. Due to not only carcinogenicity and teratogenicity effects, but also genotoxicity and other harmful environmental characteristics [6,7], 16 PAHs were listed as priority pollutants by the US Environmental Protection Agency (EPA) in 1976 [8,9], indicating that the hazards of PAH still exist after many years of restriction. The presence of PAHs originates from human and natural sources. The human sources mainly include the incomplete combustion of coal [10], petroleum, other biomass fuels, and different kinds of organic matter. In addition, PAHs are generated and exposed to humans through factory coking and automobile exhaust emissions. PAHs are also formed during natural processes, such as volcanic eruptions and through functions of aquatic and terrestrial plants and microorganisms [11,12]. In contrast, the concentration of PAHs in the air in cities is much higher than in the suburbs, which comes from the emissions from a variety of industrial factories and power plants. Therefore, due to their widespread distribution in cities, the removal of PAHs from the atmosphere and the remediation of the industrial site in cities have become the main goals of environmental governance.

\subsubsection{Properties of PAHs}

PAHs can be divided into low molecular weight (LMW) and high molecular weight (HMW) compounds. The number of rings in LMW is $2-3$, while the number of rings in HMW is 4-6. According to previous studies, the main sources of LMW PAHs include diagenetic origin or petroleum pollution, while the main source of HMW PAHs is fossil fuel combustion [13]. Studies have shown that when the ratio of LMW to HMW PAHs is lower than 1, PAHs are derived mainly from combustion heat sources. If the content ratio is higher than 1, the main source of PAHs is petroleum pollution [14]. The properties of PAHs with different molecular weights are also different. LMW PAHs are volatile and easier to be degraded in the environment than HMW PAHs, and their toxicity to organisms is relatively low. Compared with LMW PAHs, HMW PAHs are more hydrophobic, not easily volatilized, and exhibit lower water solubility [15]. HMW PAHs also have a relatively large negative impact on the environment. Due to their long half-life, HMW PAHs exist for a longer time in the environment and are more easily adsorbed to the soil [16]. The properties of LMW PAHs and HMW PAHs are listed in Table 1.

Table 1. Properties comparison of LMW PAHs and HMW PAHs.

\begin{tabular}{lcccc}
\hline PAHs & Number of Rings & Main Source & Physical Property & Persistence \\
\hline LMW & $2-3$ & Diagenetic origin; petroleum pollution & Volatile; easier to be degraded; low toxicity & Low \\
\hline HMW & $4-6$ & Fossil fuel combustion & Hydrophobic; not volatile; low water solubility & High \\
\hline
\end{tabular}

\subsubsection{Hazards of PAHs}

PAHs are the most toxic components of petroleum, with high-fat solubility and easy accumulation in the human body that can be entered and transferred into the body through the respiratory pathway, hand-mouth exposure pathway, and food chain [17]. PAHs enter the human body and interfere with the cell membrane and enzyme system, resulting in toxicity to human organs and thereby organ damage; in addition, PAH metabolites may also bind to DNA, damaging biological cells [18]. PAHs of HMW are more toxic to the human body, and human exposure to PAHs of HMW adsorbed on environmental particles may increase the risk of cancer and other diseases [19]. Since they also have a great impact on fish health, PAHs have attracted much attention in recent years [20]. The main mechanisms 
of toxicity of PAHs in fish are the metabolic activation of contaminants, production of active intermediates by PAHs, activation of aromatic receptors, and regulation of aromatic receptor-dependent genes. In addition, damage to the highly developed DNA repair system in fish, along with the presence of PAHs metabolic intermediates forming DNA adducts with genotoxicity and carcinogenicity properties, can induce mutation or cancer [21]. Among the 16 PAHs listed as priority pollutants by US EPA, 7 PAHs are carcinogenic, all of which are HMW PAHs [22]. PAHs with specific physical and environmental characteristics have caused harm to humans, other organisms, and the ecological environment, and their negative effects have increased through time. In recent years, PAHs pollution exists in the atmosphere, water, and soil. Therefore, the policies for pollution control and environmental protection of PAHs should be adopted.

\subsection{Status of PAHs Pollution in the Soil Environment}

The soil system is a major sink of PAHs deposition in the environment $[23,24]$ and stores more than $90 \%$ of the environmental mass of PAHs [25]. It is also the source of PAHs. The exchange of PAHs in soil and other environmental media includes mainly gas-soil exchange and water-soil exchange [26]. There are many sources of PAH soil pollution, for example, in the processing of medical drugs, due to imperfect procedures and legislation and high costs, a large number of pollutants enter the soil $[27,28]$. PAHs are commonly present in soil and, therefore, difficult to degrade [29]. At present, farmland pollution and site pollution have attracted much attention. PAHs pollution in farmland reduces farm productivity. The surrounding industrial areas and the areas with municipal wastewater treatment plants are relatively more at risk due to higher levels of PAHs pollution, thus requiring more attention and protection. According to the relevant research data, urban soil has become the main sink of PAHs [30], characterized by much higher concentrations of PAHs compared to suburban and rural soils, which is related to dense population, human activities, and especially the presence of industrial areas in cities [31]. In addition, $\mathrm{Qu}$ et al. [32] studied the potential sources of PAHs in the topsoil of urban parks in Beijing, China, indicating that PAHs in urban soils are usually classified according to their ring numbers. Moreover, they found that PAHs with different rings caused different levels of contamination in soil, with the contribution rates of $45.95 \%>27.38 \%>16.43 \%>6.38 \%>3.86 \%$ for 4 rings, 5 rings, 3 rings, 6 rings, and 2 rings, respectively. Thus, HMW PAHs had greater contribution rates. However, studies have shown that adding mineral fertilizers to organic fertilizers can lead to a significant increase in soil biological activity. This is mainly due to the increase in plant biomass production, which will stimulate soil biological activity after incorporation. The soil quality enzyme index calculated according to the enzyme activity value of different fertilizer types shows that valuable information about soil fertility status can be obtained through the determination of enzyme activity. Therefore, the rational use of organic fertilizers helps to keep the soil healthy [33,34]. Furthermore, Sarma et al. [35] focus on the various case studies where plant-microbe association has been used to assist the bioremediation process of PAHs and heavy metals in oil-contaminated soil. In contrast to the research of Sarma et al., the novelty of this present study is that the mechanisms of plant and microbial remediation of PAHS-contaminated soil under different conditions are discussed further. At the same time, the regulation mechanism of enzymes involved in plant and microbial degradation of PAHS in soils is studied.

\subsection{Remediation Technology for PAHs-Contaminated Soil}

The concentrations of PAHs in soil have increased worldwide during the last three decades, especially in industrial areas; due to increased anthropogenic emissions, this trend may continue in the next few years. However, PAHs have long been a threat to the environment and human body, with known potential toxicity, and therefore the remediation of PAHs-contaminated sites is particularly important [36]. The remediation methods for PAHs-contaminated soil mainly include physical, chemical, and biological.

At present, more remediation methods have been developed with technology. 


\subsubsection{In Situ Thermal Absorption Method}

In the in situ thermal absorption method, PAHs are physically separated from the soil by heating the contaminated soil. PAHs in the soil volatilize quickly under a heating system to remove PAHs from the soil, thus completing the soil remediation. The heater will raise the temperature above 800 degrees Celsius and it cannot be used in field conditions if any plants are growing in the treated soils. Therefore, this is the limitation of the in situ thermal absorption method. Using the carrier gas or vacuum system in the repair process, volatile PAHs are swept into the gas treatment system for offsite or secondary treatment, and thus few or almost no volatile PAHs are discharged into the atmosphere. Therefore, this technology to perform soil remediation is considered relatively safe [37]. In addition, the efficiency of in situ thermal absorption technology is higher. The longer the soil is heated, the stronger the restoration effect. The soil restoration rate can reach $90 \%$ for a period of three to six months [38]. However, this technology also has some drawbacks. Due to different treatment conditions and sites, the soil may be contaminated with other pollutants at high temperatures, resulting in soil remediation problems. For example, different clay minerals in soil will release fluorine pollutants at high temperature, causing secondary pollution [39].

\subsubsection{Chemical Oxidation Method}

Chemical oxidation is an in situ treatment technology in which chemical oxidants are injected into the PAHs-contaminated soil and mixed with it to effectively degrade HMW and LMW PAHs [40]. Chemical oxidation technology includes the permanganate oxidation method, $\mathrm{H}_{2} \mathrm{O}_{2}$ oxidation method, among others. To repair the soil, pollutants are finally transformed into nontoxic substances such as $\mathrm{CO}_{2}$ and $\mathrm{H}_{2} \mathrm{O}$. The chemical oxidation method used for the remediation of PAHs-contaminated sites has a good treatment effect, complete repairability, short cycle time, and low economic costs. However, related studies have shown that when chemical oxidation technology is used to repair PAHs-contaminated sites, the ultimate treatment effect depends mostly on the availability of PAHs [41]. Specifically, selective degradation of PAHs was observed by magnetite-activated persulfate oxidation with lower degradation efficiency towards high molecular weight PAHs [41]. On the other hand, PAH unavailability and soil matrix effect seem to be the most important factors for the persulfate oxidation process. Selective degradation behavior was shown by persulfate oxidation with less efficiency towards HMW PAHs [41].

\subsubsection{The Status of Bioremediation Technology Microbial Remediation}

Bioremediation is a widely recognized soil clean-up remediation technology, which uses the metabolic activities of microorganisms and plants to minimize or eliminate PAHs in the soil, thereby completing soil remediation. In this technology, contaminants are not transferred from one medium to another, and thus this repair technology is relatively safe, environmentally friendly, and also economical [42].

Remediation of polluted sites using microbes is an early and widely used bioremediation method and therefore considered to be one of the main processes for PAHs removal from soil and also the main natural removal pathway. In particular, fungal-based remediation, which involves adding one or more PAHs-degrading fungal species to the soil, can accelerate the natural degradation of PAHs [43]. One of the main reasons to perform fungal-based remediation for the elimination of PAHs and purification of soil is that they can produce lignin-degrading enzymes that use PAHs as substrates. Due to the low substrate specificity of this enzyme, PAHs can be degraded [44]. In addition, the composition and structure of microbial communities are also key factors influencing the degradation of PAHs [45]. Bellino et al. [46] used a new soil microbial ecology method to evaluate the role of different microbial groups in the degradation of PAHs and found that fungi and actinomycetes played a major role in the degradation of these pollutants in soils treated with composts and fungi. 
Microbial technology refers to a method that uses microorganisms to eliminate or harmlessly treat PAHs in the soil or water under the influence of human intervention or natural factors. The addition of exogenous microorganisms that can decompose organic pollutants, which is the way to remediate contaminated soil, is called enhanced biological treatment. Enhanced biological treatment refers to the use of microbial treatment technology to treat contaminated soil. At the same time, adding trace elements and acid-base salts that are beneficial to the growth and development of microorganisms in the contaminated soil. This method can promote the reproduction and division of microorganisms and enhance the governance level $[47,48]$. Tiwari et al. [49] found that microorganisms can biodegrade hydrocarbon compounds and are often used to remediate oil-contaminated soil [49]. The results also show that microorganisms such as fungi in the rhizosphere can also remove soil pollutants such as pentachlorophenol and DDT to a certain extent [50].

The degradation of PAHs by microorganisms requires the cooperation of multiple enzymes to provide energy for effective treatment and removal of pollutants. When microorganisms are stimulated by PAHs in a contaminated site, the microorganisms can release enzymes that have a certain degradation or conversion effect on PAHs. Such enzymes undergo hydrogenation, dehydration and other reactions, so that the $\mathrm{C}-\mathrm{C}$ bonds on the benzene ring of PAHs are broken, and then decomposed into small molecular monomers with less toxic effects [51]. When the bacteria in the soil are stimulated by PAHs, the enzymes produced also increase the number of oxygen atoms on the benzene ring of polycyclic aromatic hydrocarbons, forming a series of oxides, followed by further oxidation reactions to promote the removal and conversion of PAHs. Partially oxidized and decomposed polycyclic aromatic hydrocarbons can become a source of nutrients that are directly used by microorganisms and finally oxidized into $\mathrm{CO}_{2}$ and $\mathrm{H}_{2} \mathrm{O}$, thus promoting the growth and development of microorganisms.

The structural complexity of polycyclic aromatic hydrocarbons is directly proportional to their stability in soil. The more complex the structure, the less likely it is to be naturally degraded in the soil. There are a small number of microbial species in the soil that can directly transform or decompose PAHs with complex structures. These are mostly degraded through the common metabolic mechanism, which is conducive to the growth of microorganisms and pollution, and also meets the needs of their growth and development while degrading substances [52]. The study conducted by Zhao et al. [53] has shown that soil $\mathrm{pH}$, humidity, and temperature of the environment are important physical and chemical factors that affect microbial activity and have far-reaching significance for the remediation of polluted sites using microbes.

\section{Phytoremediation}

Phytoremediation of pollutants is a method that uses plants to eliminate organic pollutants from the surface soil, atmosphere, and water in the natural environment. Compared with other remediation technologies, the cost of phytoremediation is lower, it affects water, soil, and atmospheric environments less, and it has a profound restoration effect without causing recontamination [54,55]. Most previous phytoremediation technologies focused on the removal of toxic heavy metals from the soil by plants. In recent years, studies have shown that plants have a certain ability to remove organic pollutants such as polycyclic aromatic hydrocarbons and polychlorinated biphenyls from the soil [56,57]. The selection of an efficient remediation technology according to the type of pollution and the degree of pollution is conducive to rapid and secondary pollution-free soil remediation. For contaminated soils containing high concentrations of organic pollutants and with a high environmental risk coefficient, chemical or physical remediation technology is used to remediate the soil. For soils with a low number of pollutants and a low degree of pollution, treatment technologies using the combination of plant and microorganisms are often used [58]. The main phytoremediation pathways are shown in Table 2, and the schematic diagram of phytoremediation methods is shown in Figure 1 [59-62]. 


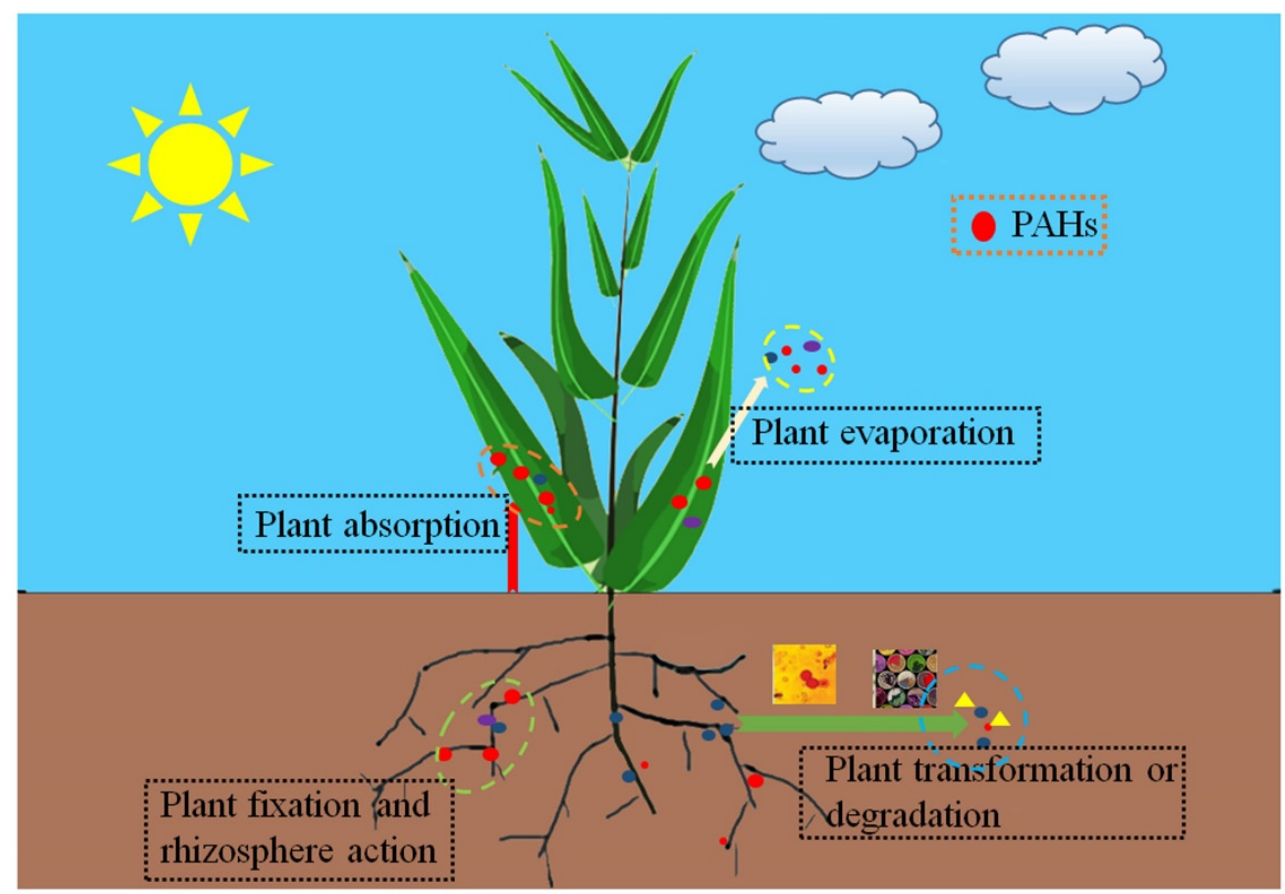

Figure 1. Schematic diagram of PAHs in phytoremediation process.

Compared with physical and chemical remediation, phytoremediation has some drawbacks. For example, the treatment cycle in phytoremediation is longer, and thus the contaminated soil cannot be quickly repaired. When considering phytoremediation, local natural conditions and climatic conditions should be taken into account. Plants that are adapted to the local climate are selected for soil management and restoration, and they also need to be protected from pests and diseases on a schedule; otherwise, the restoration would be affected. Phytoremediation is not suitable for soils with high pollution levels. Most plants exhibited growth inhibition and retardation in the environment with high pollution levels $[63,64]$. At the same time, after the accumulation and enrichment of pollutants by plants, the treatment of "contaminated plants" is also a problem that must be addressed in the restoration process.

Phytoremediation is a safe, economical, and environmentally friendly soil remediation method, which involves degradation, absorption, metabolism, and transformation and uses related rhizosphere microorganisms to reduce the concentrations of PAHs in soil [65]. Previous studies have shown that the combination of some legumes and other plants can accelerate the elimination of PAHs from soil [66]. Specifically, Benjamin et al. [57] researched different levels of plant species richness $(1,2,4,8,16,60$ species) and 1-4 plant functional groups (grasses, small herbs, tall herbs, and legumes) in a randomized block design. The concentrations $\left(\mathrm{ng} \mathrm{g}^{-1}\right)$ of $\sum 15$ PAHs in the soils were 57-329. Concentrations of 16 (out of 44) $\sum 29$ PAHs decreased significantly with increasing plant species richness, after accounting for the effects of block and initial soil organic $C$ concentration (ANCOVA, $p<0.05)$. Moreover, in this soil remediation method, mostly grasses, such as ryegrass were used. Using different plants to degrade PAHs can improve the population structure of rhizosphere microorganisms, resulting in different effects on the elimination of PAHs. However, the removal of PAHs by phytoremediation mainly involves degradation using plants, and absorption plays a minor role [67]. 
Table 2. The main pathways of phytoremediation of PAHs-contaminated soil.

\begin{tabular}{ccc}
\hline Repair Methods & Repair Process \\
\hline Plant absorption method & $\begin{array}{c}\text { Through the absorption of plant rhizosphere, the organic pollutants in the soil are } \\
\text { concentrated in the plant body, which can decompose the pollutants. When the } \\
\text { concentration of pollutants in the plant body exceeds the decomposition capacity of } \\
\text { the plant, the organic pollutants will accumulate in the plant body. }\end{array}$ \\
\hline [68] & $\begin{array}{c}\text { Plant roots exude a series of secretions, which can change the soil environment } \\
\text { around plant roots, such as soil moisture, soil hardness, pH, and other soil } \\
\text { conditions. Plant root exudates can also interact with organic pollutants in the soil, } \\
\text { reducing the biological activity of pollutants. }\end{array}$ \\
[69] & $\begin{array}{c}\text { Through the absorption of plant rhizosphere, the organic pollutants in the soil are } \\
\text { concentrated in the plant body, and the organic pollutants are discharged into the } \\
\text { plant body through transpiration. }\end{array}$ \\
[70] & $\begin{array}{c}\text { The organic pollutants in plants can be decomposed into nontoxic and harmless } \\
\text { substances through the physiological activities of plants, and the root exudates of } \\
\text { plants also have a certain ability to degrade the organic pollutants in soil. }\end{array}$ \\
[71] & $\begin{array}{c}\text { Plant rhizosphere root exudates act on organic pollutants, and decomposed organic } \\
\text { pollutants can become carbon sources for microorganisms in the soil, which is } \\
\text { conducive to the reproduction of microorganisms in the soil and provide a good } \\
\text { living environment for microorganisms in the surrounding soil of the rhizosphere. }\end{array}$ \\
\hline [72]
\end{tabular}

Comparing various restoration technologies, it is obvious that they all have their strengths and weaknesses, but in the long term, phytoremediation is undoubtedly a restoration technology with good developmental prospects. Using biological hybridization techniques to change the adaptation of plants to the soil environment and natural climate, plants with a tolerance to highly polluted soils should be selected and used in conjunction with microorganisms to repair the plants to ensure a promising approach for soil remediation in the future. Plants can initially degrade and transform polycyclic aromatic hydrocarbons and then use the decomposed products as nutrients to meet their growth and developmental needs. Compared with traditional techniques, the remediation technologies using plants have gained more attention in particular countries and regions [73].

\section{Phytomicrobial Remediation}

PAHs are chemically stable and easily affected by other elements in the environment, which limits their bioavailability and bioremediation efficiency, thus increasing the difficulty of pollution remediation [74]. At present, both microbial and plant remediation technologies have certain shortcomings, and the joint remediation technology between the two has the characteristics of short processing time, high remediation efficiency, environmental protection, and high efficiency. Therefore, this method has become the most promising remediation method and research hotspot for remediation of PAHs-contaminated soil [75]. By using nucleic acid extraction and cDNA synthesis, Song et al. [76] studied the degradation and removal of PAHs from a coking plant soil by four natural herbaceous plants (Ambrosia artemisiifolia L.; Herba Artimisiae Sieversianae.; Setariaviridis (L.) Beauv.; Kochia scoparia (L.) Schrad.) and the effects of soil properties and bacterial community composition on the potential of plant rhizosphere to repair PAHs-contaminated soil. This review provided a theoretical basis for remediation of PAHs from the rhizosphere and helped clarify the plant-microorganism interaction in the rhizosphere remediation of PAHs-contaminated soil. Many studies have shown that biostimulation is more efficient than biofortification in the remediation of PAHs-contaminated soils [77]. Biostimulation is a method of altering the activity and strength of microorganisms in biodegradation, including regularly adding nutrients and carbon sources to contaminated soil, together with adding external stimulus conditions. Biofortification is the process of increasing the rate of biodegradation by adding bacteria or archaea. For example, adding an appropriate amount of biochar can provide a favorable environment for microbial survival, while changing microbial 
community structure and activities [78]. Biochar can also contribute to the degradation of target pollutants [79-81], promote plant growth, and reduce the concentrations of PAHs in soils and plants [82], thus making it a promising remediation method [83]. Surfactants can increase not only the poor water solubility of PAHs [84] but also improve their bioavailability. In addition, since surfactants also can enhance the biodegradation of PAHs and speed the bioremediation rate, surfactants can be added to the bioremediation process. Mixed surfactants are more effective in enhancing the biodegradation of PAHs. Li et al. [85] found that anionic-nonionic mixed surfactants can improve soil microbial community structure, increase the biodegradation capacity of PAHs, and change the membrane permeability of plant roots, thereby affecting their absorption behavior through roots.

Farmland soil remediation is different from site soil remediation. Although physical, chemical, and biological methods can degrade PAHs, they have certain limitations in farmland soil remediation [86]. These limitations include low remediation efficiency and high economic costs for aged soil and HMW PAHs-contaminated soil. Therefore, joint methods, such as physical-chemical, chemical-biological, and biological-biological, are adopted for the remediation of most of the farmland PAHs-contaminated soils [87].

In recent years, people have paid more attention to the restoration of typical organic soils abandoned by relocated companies. Among the existing methods and countermeasures used for the restoration of PAHs-polluted soil, land farming and bioremediation have gained more popularity. However, due to the constraints associated with various environmental factors such as the toxicity of pollutants and nutrients, these remediation methods cannot effectively repair the soil [88]. The combined treatment using plants and microorganisms deals with different types of soil pollution and can effectively treat the contaminated soil. The secretions around plant roots can stimulate the activity of microorganisms in the soil to oxidize PAHs. The combined action of plants and microorganisms around the roots changes the characteristics of the soil in different ways, enhances microbial degradation, and promotes the oxidative decomposition of pollutants by plants [89,90]. Different types of plants, especially grasses, have a huge rhizosphere system, which can produce large amounts of organic matter in the soil. In the rhizosphere of plants, the migration of PAHs in the soil and the spread of PAHs to surrounding sites can be slowed. The transfer, with a certain stabilizing effect on PAHs, is conducive to the mineralization of bacteria or fungi and leads to more soil organic matter consumption. The growth of plant roots can help loosen the soil, enhance air permeability, and facilitate the entry of water and air. The acidity and alkalinity of the soil can be altered to facilitate the adaptation of microorganisms to survive. The decomposition and transformation of the fallen leaves and branches of plants provide nutrients for plant growth and development, and the presence of bacteria and fungi also stimulates the rhizosphere of plants. The existence of plants and microorganisms that are conducive to the uptake of nutrients in the soil is a complementary and synergistic way to promote the degradation of pollutants in the soil [91,92].

The synergistic treatment of soil by plants and microorganisms is a comprehensive utilization of the ability of plants and microorganisms to degrade PAHs. The addition of fungi and bacteria has certain effects on some specific PAHs with polyphenyl rings. The high treatment capacity greatly improves the efficiency of soil remediation. Therefore, the introduction of plants into the bioremediation system can overcome the limitations associated with other bioremediation methods to repair the small biomass of soil and improve the degradation of pollutants. In addition, soil microorganisms, as an indicator for soil pollution, can be used to evaluate the toxicity, risk status, and remediation of contaminated soil and also assess the risk of final metabolites of organic matter $[90,91,93,94]$.

\subsection{Concentrations of PAHs in Farmland Crops}

The effect of polycyclic aromatic hydrocarbon pollution on crops is far-reaching. The analysis of the concentrations of PAHs in some farmland vegetable crops showed lower concentrations of high molecular weight PAHs in most vegetables compared to those of low molecular weight PAHs. Fismes et al. [95] and others reported that carrots, 
potatoes, and lettuce can absorb polycyclic aromatic hydrocarbons from contaminated soil. Camargo and Toledo [96] also observed that grapes, apples, pears, tomatoes, cabbage, and lettuce, grown in rural areas near Brazilian urban centers, contain PAHs. In some research areas, where wastewater containing polycyclic aromatic hydrocarbon mixtures was used to irrigate vegetables, PAHs were also detected in cultivated vegetable crops. Radishes, coriander, cauliflower, cabbage, etc., were cultivated in soil containing polycyclic aromatic hydrocarbons. Carrots, turnips, peas, lettuce, garlic, onions, and other crops also have different levels of polycyclic aromatic hydrocarbons. Two vegetables, cauliflower and lettuce, are the most contaminated, with a maximum value of $276 \mu \mathrm{g} / \mathrm{kg}$ [97], while in the Bannu district (lightly polluted region) cabbage was observed highly contaminated vegetable with PAHs of $177 \mu \mathrm{g} / \mathrm{kg}$. In addition, in leafy vegetable, NA (2 ring PAH) ranged from 35 to $55 \mu \mathrm{g} / \mathrm{kg}$, while $\mathrm{ACN}, \mathrm{Fl}, \mathrm{PHE}$, and $\mathrm{AN}$ ( 3 ring PAHs) ranged from 9 to $86 \mu \mathrm{g} / \mathrm{kg}$. HMW-PAH, including FlA, BaP, CHR, and PY (4 ring PAHs) ranged from 2 to $70 \mu \mathrm{g} / \mathrm{kg}$, while BaP, BbF, and BkF (5 ring PAHs) ranged from 2 to $42 \mu \mathrm{g} / \mathrm{kg}$, and D(ah)A, $\mathrm{B}$ (ghi)P and IP (6 ring PAHs) ranged from below detection limit to $7.2 \mu \mathrm{g} / \mathrm{kg}$. The content of PAHs in cabbage and leafy vegetable is far less than that in cauliflower and lettuce, indicating that the pollution of cauliflower and lettuce is indeed the most serious. Using the plant concentration factor $(\mathrm{CF})$ to estimate the human risk of PAHs in vegetables, $\mathrm{CF}$ values of all individual PAHs (both LMW and HMW) for selected vegetable were observed less than one. It means that no vegetable was shown the hyperaccumulating capacity towards PAH accumulation [97]. Studies have also recorded the PAHs concentrations in soybeans, peanuts, rice, cowpea, and other crops at different distances along the road in the same area and also in rural areas and found that the closer the distance to the road, the higher the concentrations of polycyclic aromatic hydrocarbons in crops, with more crops on the roadside. Specifically, the highest mean detection value $(2887.73 \mathrm{ng} / \mathrm{g})$ of $\Sigma 16 \mathrm{PAHs}$ occurred at the sampling point $10 \mathrm{~m}$ away from the road, while the lowest mean detection value (172.78 ng/g) of $\Sigma 16$ PAHs occurred at the sampling point $20 \mathrm{~m}$ away from the road, and the highest mean value was 16.7 times of the lowest value. The average detection value of $\Sigma 16$ PAHs of farmland along the highway was $966.39 \mathrm{ng} / \mathrm{g}$, while the average detection value of $\Sigma 16$ PAHs of farmland near urban road was $220.68 \mathrm{ng} / \mathrm{g}$. The $\Sigma 16$ PAHs of highways were 4.39 times that of urban roads [98]. Through analysis, it can be seen that crops can absorb PAHs through soil, water, air and other means, causing serious harm to human health. Therefore, reducing the PAHs in soil and other media can indirectly reduce the content of PAHs in the human body, thereby reducing the harm of PAHs to the human body.

So far, many researchers have evaluated the residual amount and pollution degree of PAHs in the soil by collecting samples, and used a single method to remediate the contaminated soil. However, considering that previous studies were conducted on some types of PAHs in individual areas, the overall research work is relatively scattered, and it is impossible to fully and multidimensionally recognize the impact of PAHs on the entire society. Therefore, the significance and novelty of this review are to collect and sort the more important earlier research results of PAHs, summarize the current research progress of PAHs, and aim to reveal the mechanism of the plant-microbes to efficiently remediate the soil contaminated by PAHs, and solve the problem from the source. The limitation of phytomicrobial remediation of PAHs-contaminated soil provides theoretical guidance for regulating the ecological risks caused by PAHs pollution in the soil.

\section{Factors Affecting the Remediation of PAHs-Contaminated Soil by Plants and Microorganisms}

2.1. Influence of Structure and Physicochemical Properties of PAHs on the Phytomicrobial Remediation of Contaminated Soil

The structure, physical, and chemical properties of PAHs also have a certain impact on the remediation of contaminated soil by plants and microorganisms. Plants generally have better degradation ability to PAHs with smaller molecular weight; on the contrary, their degradation ability is poor, such as complex molecules containing more benzene 
ring structures. This is mainly because PAHs with larger molecular weight have strong absorption capacity in soil, so they are not easily degraded by plants [99]. Different PAHs have different degradability and absorption capacities, with different toxic effects on plants due to their different chemical structures. Taking PCBs as an example, the greater the number of chlorine substituents on the carbon skeleton, the greater the biotoxicity and bioaccumulation. In addition, compared to the PCBs substituted by the meta position of the chlorine group, the PCBs where the adjacent positions are simultaneously substituted by the chlorine group are more toxic. The ability of plants to oxidize and decompose PAHs in contaminated sites is related to PAHs structures, bioaccumulation, mobility, and degradability $[100,101]$.

\subsection{How Characteristics of Plants and Microbes Influence Their Remediation of PAHs-Contaminated Soil}

Different plant species have different characteristics, and their ability to transform and absorb PAHs also differ [102]. Studies have shown that PAHs containing chlorine substituents are mainly accumulated on the roots of plants due to their great bioaccumulation ability, but their content in other parts of the plant is very small. The transport capacity of aromatic hydrocarbons in plants is limited, and pollutants cannot be transferred from the roots of plants. Recent studies have found that cucumbers and zucchini that belong to the genus Cucurbita have certain concentrations of organic pollutants such as PAHs containing chlorine substituents, but the content of organic matter in zucchini is significantly higher than in cucumber. Zucchini mainly relies on the root system to enrich organic pollutants such as PAHs containing chlorine substituents, while cucumber mainly relies on leaves [103]. Although the mechanism of phytoremediation of soil is not particularly clear at present, most published research findings have shown that different root exudates and enzymes in different plants are the main reasons for the differences in the degradation of PAHs by plants [104]. Studies on the ability of different species of plants to remove PAHs have found that most plants with better removal capacity have developed root tissues. The roots are the tissues and organs that directly contact PAHs. The large specific surface area of the roots is beneficial, as it fixes and enriches pollutants, and the rhizosphere is a favorable environment for the growth of bacteria and fungi that exist within the rhizosphere. The capacity of grasses to remove PAHs is higher than that of herbaceous plants. The different root exudates of plants also have different capacities to remove these pollutants. Different polycyclic aromatic hydrocarbons also play different roles, and their degradability with different molecular weights also differs. Only through the synergistic effect of plants and microorganisms that promote each other can the remediation ability be improved [105-107].

\subsection{Influence of External Factors on Phytomicrobial Remediation of PAHs-Contaminated Soil}

Moisture is an important factor influencing PAHs degradation and can directly affect the oxygen content in the soil. For example, it is difficult for aerobic microorganisms to degrade organic pollutants in the soil under flooding conditions. The water content can hinder the circulation of air in the soil. Oxygen in the air helps improve the oxidative decomposition of PAHs by aerobic microorganisms. The degradation of PAHs by bacteria and fungi requires the participation of oxygen. Furthermore, the content of oxygen in the soil is an important constraint that affects the activities of bacteria and fungi in soil management. If the soil surface is too compacted, the oxygen in the air will not enter the soil, with an inhibitive effect on the survival of aerobic microorganisms. Moreover, if the soil overall is too compacted, the particles and organic pollutants in the soil are more closely combined, which is not conducive to the oxidative decomposition and removal of PAHs. The use of surfactants is also conducive to enhancing the removal of PAHs and increasing soil repair and removal rate. Related studies have demonstrated that the quantitative addition of surfactants to contaminated soil is beneficial to desorption and conversion of PAHs by bacteria and fungi in the soil, and it improves the degradation efficiency. Furthermore, compared with PAHs with polyphenyl rings, it is easier for those 
with a low number of benzene rings to be absorbed and degraded [108-111]. High water content in the soil is conducive to the occurrence of aerobic degradation and its reactions. The difference in soil quality would also affect the populations of microorganisms. Studies have shown that the bacteria are cultivated in paddy soil and red sandy soil with lower organic matter contents. Bacteria in red sand soil went through fewer changes, while the population of bacteria isolated from the paddy soil in the medium rose rapidly after 14 days of culture, reached the peak at about 28 days, and then decreased [112]. Studies have also compared the effects of adding mineral nutrients such as $\mathrm{N}$ and $\mathrm{P}$ to the soil, and found that $\mathrm{N}$ and $\mathrm{P}$ nutrients can promote the oxidation and decomposition of PAHs by bacteria and fungi in the soil. However, the addition of mineral nutrients has almost no effect on the degradation of PAHs. When further adjusting the ratio of nutrients such as $\mathrm{N}$ and $\mathrm{P}$ added to the soil, it is found that the ratio of adding $\mathrm{N}$ and $\mathrm{P}$ is different, and the effect of the bacteria and fungi in the soil on the decomposition of PAHs will also be different [113]. Studies have shown certain differences in the amounts of nutrients needed to add to the soil to treat PAHs of different molecular weights. When the same proportion and content of nutrients are added to the soil, degradation of PAHs with different molecular weights can also occur at different levels. Elements such as $\mathrm{N}$ and $\mathrm{P}$ are beneficial to oxidation and decomposition of low molecular weight PAHs but have little effect on the removal of high molecular weight PAHs [114,115].

\section{Phytoremediation Mechanism of PAH Transformation in Contaminated Soil}

Compared with other remediation methods, phytoremediation is more economical and effective for the treatment of PAHs-contaminated soil. At present, the research focus is on screening and cultivating plants with high accumulation and enrichment capacities [116] to achieve the purpose of remediation of polluted soil by improving tillage practices [117]. Scientists have also tried to simulate the phytoremediation of contaminated soil with the help of dynamic equilibrium models [118]. Plant variety [119], molecular physical and chemical properties [120], soil type [121], and other factors are closely related to phytoremediation efficiency. PAHs can be absorbed by plants from the soil and transferred to root, stem, and leaf tissues, and the enzymes secreted by endophytic bacteria can be used to degrade PAHs. Plants can absorb PAHs from contaminated soil and transfer them to their tissue cells by glutathione S-transferase and $A B C$ transporter [122]. Brassinolide can not only significantly increase the content of reduced glutathione in plants but also greatly enhance the biological activity of glutathione S-transferase [123]. The mineralization degradation of PAHs through plant metabolism mainly involves PAHs hydrolysis, redox, and other reactions [124]. Moreover, $\alpha / \beta$-hydrolase plays a key role in the hydrolysis of PAHs [125]. In addition, cytochrome P450, peroxidase, polyphenol oxidase, and laccase play key roles in the phytodegradation of PAHs [126].

Root exudates produced by plant metabolism also play a significant role in the degradation and mineralization of PAHs in contaminated soil. Root exudates provide nutrients and energy for microbial reproduction and act as a bridge link for the interaction between plants and microorganisms. Since the composition of root exudates of different plant species also differs, the metabolic activity and diversity of rhizosphere microorganisms vary to different degrees [127]. Root exudates can be divided into low molecular weight and high molecular weight [128]. Among them, low molecular weight (organic acids) and high molecular weight (extracellular enzymes, and peroxidases) play a positive role in improving the degradation of PAHs [129]. PAHs can induce the secretion of more organic acids in plants, and organic acids can accelerate the separation of PAHs from soil particles [130]. Plant extracellular enzymes can directly degrade and mineralize organic pollutants in soil media [131]. Research on the remediation of benzo [a] pyrene contaminated soil with ryegrass by Ding et al. [132] found that the increase of the content and activity of polyphenol oxidase in the soil medium had a significant positive effect on the improvement of the degradation rate of benzo [a] pyrene. Bacteria can secrete biosurfactants stimulated by water-soluble organic acids in the rhizosphere, which play 
an important role in improving the biochemical utilization efficiency and accelerating the degradation of PAHs [133]. Kim et al. [134] found that within a certain limit, the absorption rate of anthracene in contaminated soil would significantly increase with the increase of the amount of water-soluble organic acids in alfalfa, and the variation range was $80 \%$. The interaction between root exudates and rhizosphere microorganisms is of great significance in the phytoremediation of PAHs-contaminated soil.

\section{Transformation Mechanism of Microbial Remediation of PAHs in Contaminated Soil}

Microbial activity has become one of the most important mechanisms for the remediation of PAHs-contaminated soil because microorganisms are ubiquitous in the environment. When studying the mechanism of PAHs biodegradation, scientists mostly focus on naphthalene and phenanthrene with fewer than four rings [135-137]. Although PAHs can be mineralized under both aerobic and anaerobic conditions, aerobic degradation is significantly superior to anaerobic degradation in terms of degradation rate [138].

\subsection{Transformation Mechanism of Anaerobic Bioremediation of PAHs in Contaminated Soil}

The more complex the chemical structure of the target pollutant is, the more difficult the degradation by anaerobic microorganisms would be [139]. The most significant factors affecting the degradation of PAHs by anaerobic microorganisms are the physical and chemical properties of the molecule itself, the number of benzene rings, and the type, number, and location of substituent groups [140]. In addition, the activity of degrading enzymes secreted by anaerobic microorganisms and the mechanism of adaptation to target pollutants are also key factors determining the anaerobic degradation rate [141]. Anaerobic microorganisms can degrade low-cyclic PAHs such as naphthalene and phenanthrene, while for the degradation and transformation of high-cyclic PAHs with more than four rings, anaerobic microorganisms have the metabolism common with other types of microorganisms. Studies have shown that by changing the nutrient structure, carbon source, and energy, cometabolic anaerobic bioremediation helped absorb more nutrients, which can further exploit the potential of microorganisms to mineralize high molecular weight PAHs [142]. In recent years, studies on the mechanism of degradation of low molecular weight PAHs such as naphthalene and phenanthrene have been conducted, and the anaerobic degradation pathways are shown in Figure 2.

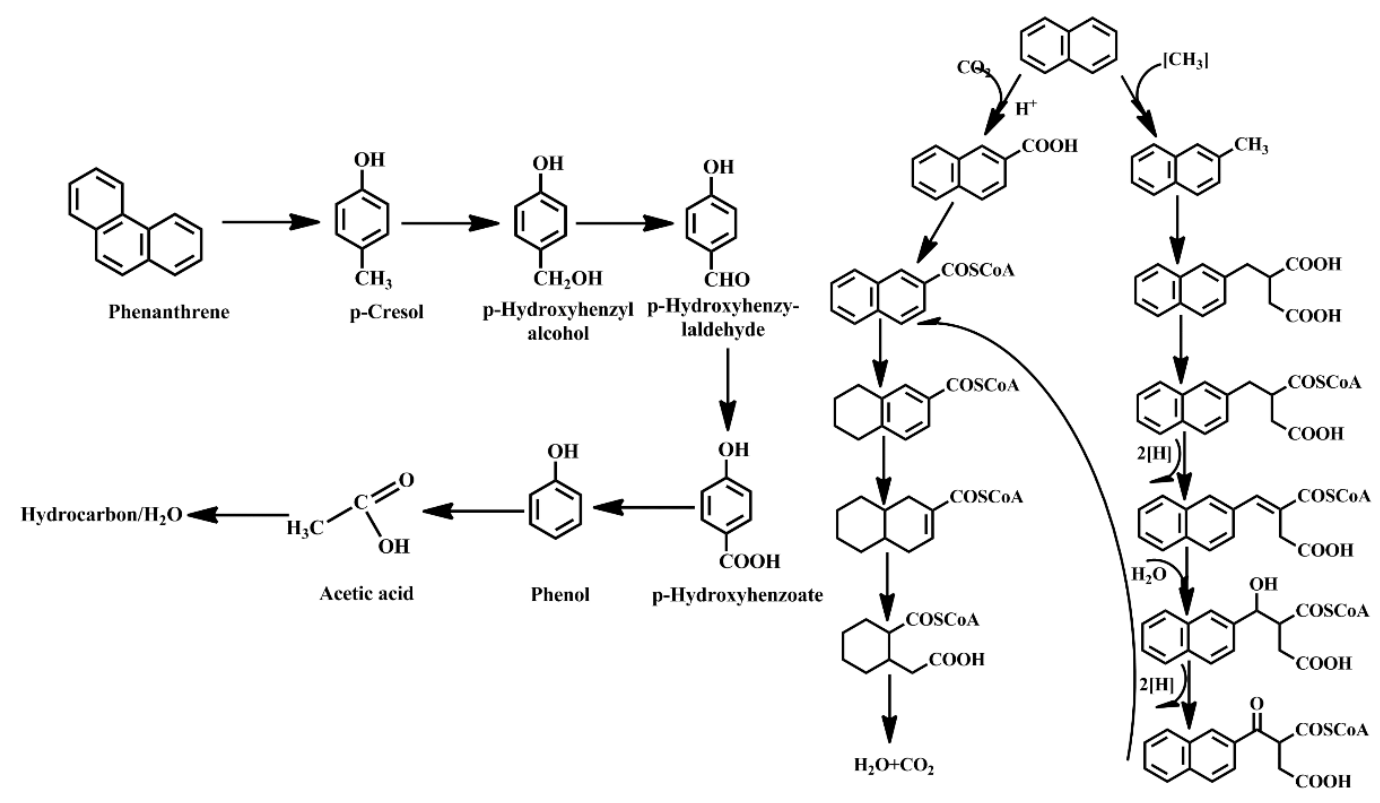

(a)

(b)

Figure 2. Anaerobic degradation pathway of phenanthrene (a) and naphthalene (b). 
The initial reactant excitation of the degradation of naphthalene by anaerobic microorganisms is mainly divided into two phases, including the carboxylation reaction at the C2 site and the methylation reaction after the introduction of fumaric acid [143]. The first initiation pathway is based on the highest electronegativity of the benzene ring at the $\mathrm{C} 2$ site; thus, electrophilic substitution reaction or carboxylation reaction can occur by attacking the carbanion of naphthalene. Zhang et al. [144] used the $13^{\mathrm{C}}$ labeling method to trace the degradation of naphthalene and confirmed that the carboxylation reaction was the initial step for the mineralization of naphthalene by anaerobic microorganisms. After adding hydrogenation coenzyme to the system, the benzene ring can undergo secondary hydrogenation, and then ring opening occurs. Finally, the molecular structure of the small-ring compound can be gradually transformed, making it easier to be degraded by anaerobic microorganisms. Safinowski et al. [145] investigated the degradation process of 2-methylnaphthalene by the anaerobic microorganism N47 and detected a variety of intermediate products. The addition of fumaric acid has been proved to cause the methylation reaction of naphthalene and generate the corresponding intermediate products. The experimental results are highly consistent with the hypothesis of the second initial activation reaction, which proves the authenticity of the second initial activation reaction. Based on the detected 2-methylnaphthalene, the metabolites were produced by the reverse reaction of its degradation. The carboxylated metabolites of naphthalene are produced through multiple reactions of 2-methylnaphthalene with dehydro coenzyme, and the resulting degradation products are highly similar to those produced by the first initial reaction. Musat et al. [146] used naphthalene as the only carbon source along with marine substrates to breed anaerobic bacteria NAPHS2 and conducted an in-depth study on the metabolism and degradation of naphthalene. Based on the detected 2-methylnaphthalene, the metabolites were generated by the reverse reaction of degradation of 2-methylnaphthalene. 2-methylnaphthalene reacts with dehydro coenzyme multiple times, is converted into carboxylated metabolites of naphthalene, and finally produces the same degradation products as the first degradation method.

Most domestic and international scholars have studied the anaerobic degradation process of phenanthrene using sulfate-reducing bacteria as the experimental object [147-149]. Tsai et al. [148] used GC-MS to isolate and detect the metabolites produced during the microbial transformation of phenanthrene by sulfate-reducing bacteria and performed a comparative analysis. They found that both cresol and phenol were detected at the same time and speculated that phenol was synthesized after the occurrence of the hydroxylation reaction of the methyl group of cresols. The general degradation pathway of phenanthrene by anaerobic microorganisms follows: phenanthrene is degraded to cresol by sulfatereducing bacteria, and then the phenanthrene is converted into hydroxybenzene methanol or $p$-hydroxybenzaldehyde by hydroxylation reaction. Para-hydroxybenzaldehyde can be decomposed into hydroxybenzoic acid and phenol, and finally, the carboxyl group on the degradation product is split off through hydration and hydrolysis to complete the anaerobic degradation of phenanthrene [149].

\subsection{Transformation Mechanism of Aerobic Bioremediation of PAHs in Contaminated Soil}

Compared with the mechanism of anaerobic biodegradation, the research on the transformation mechanism of aerobic biodegradation is more extensive and detailed. Oxygenase plays a key role in the degradation of PAHs by aerobic microorganisms [150]. When stimulated by PAHs in soil, aerobic microorganisms secrete monooxygenase and dioxygenase to mineralize PAHs, thereby remediating the polluted soil [151]. Under the influence of these degrading enzymes, the oxidation, hydrogenation, and dehydration reactions generally occur in the benzene ring in PAHs, leading to its final breakage, thereby transforming it into small-ring PAHs [152]. Studies have shown that fungi and bacteria play significantly different roles in the degradation of PAHs during the process of aerobic degradation [153]. The monooxygenase produced by aerobic fungi can oxidize the $\mathrm{C}$ on the benzene ring and further convert it into trans diol and phenol through hydration reaction [154]. Aerobic 
fungi mainly include Phellinus ribis and non-Phellinus ribis. Non-Phellinus ribis degrade PAHs mainly with the help of P450 monooxygenase, while Phellinus ribis can mineralize PAHs under the influence of synergistic action of P450 monooxygenase and a dual enzyme system for lignin degradation [155]. The degrading enzyme system and the degradation pathway are shown in Figure 3. Catalyzed by dioxygenase secreted by aerobic bacteria, the benzene ring in PAHs reacted with two oxygen atoms to generate peroxides, which were degraded into cis diol through oxidation reaction, and then converted to phenol after dehydrogenation reaction [156]. Different degradation pathways may cause the production of different types of intermediate products developed in the degradation process, and the intermediate products developed through each degradation pathway include catechol, 2, 5-hydroxybenzoic acid, and 3, 4-dihydroxybenzoic acid. The products developed by general degradation and transformation of PAHs by aerobic microorganisms can be gradually transformed into succinic acid, fumaric acid, pyruvate, and acetic acid/acetaldehyde through lysis of the benzene ring, and finally absorbed as nutrients by microorganisms to synthesize their cell proteins and generate carbon dioxide and water molecules [157]. Li et al. [158] compared and analyzed the efficiency to degrade PAHs by bacteria, fungi, and bacterial-fungal complex communities in the oil-contaminated soil. The results showed that the efficiency in degrading PAHs in three communities was $45 \sim 56 \%$, and the biochemical availability and removal efficiency of PAHs in contaminated areas could be greatly improved by pretreatment. In addition, the large specific surface area of fungi improves the chance of contact with the substrate; thereby, the rate of the degradation of PAHs by fungi is significantly higher than that of the other two biomes.

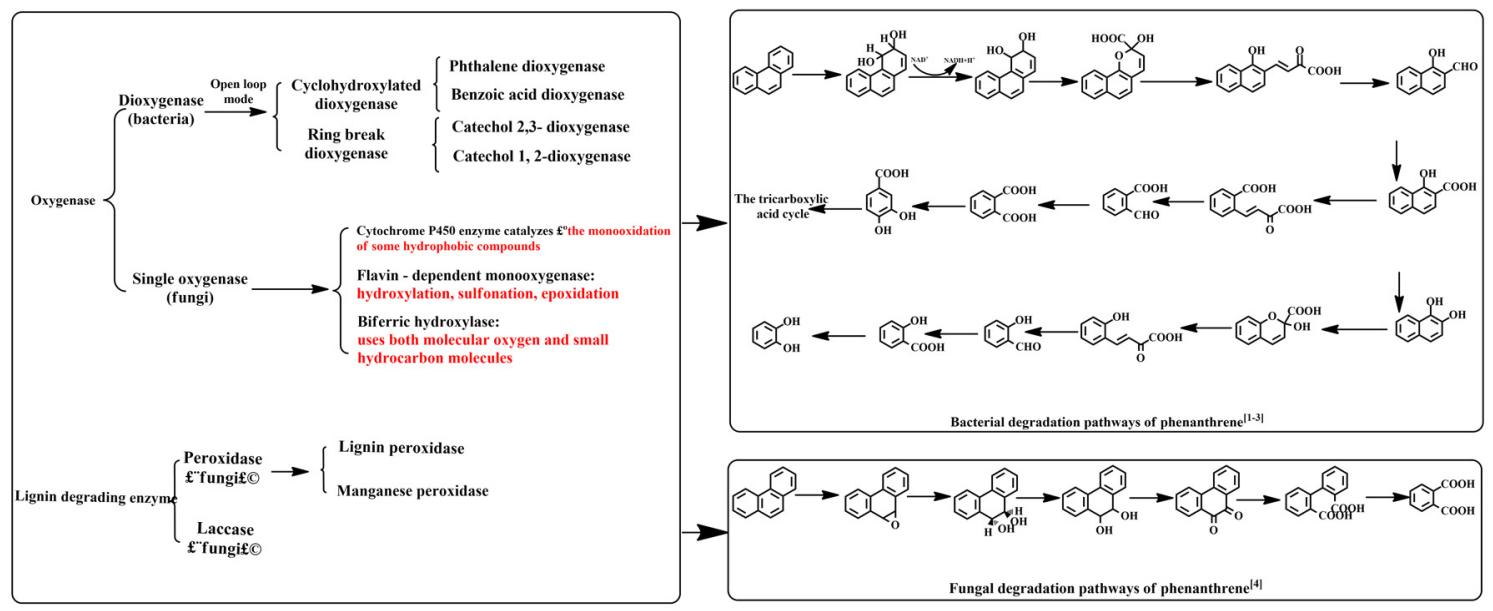

Figure 3. Composition of the enzyme associated with aerobic bacterial and fungal degradation pathways of phenanthrene.

\subsection{Synergistic Remediation of PAHs-Contaminated Soil by Fungi and Bacteria}

Although fungi and bacteria have different mechanisms for the degradation of PAHs, they can play synergistic and complementary roles in the degradation process. PAHs with more benzene rings (above the fourth ring) are the main targets for fungal degradation, while bacteria have the greatest ability to degrade middle- and small-ring PAHs. Studies have shown that the synergistic degradation by bacteria and fungi can greatly increase the degradation rate of large-ring PAHs [159]. Boonchan et al. [160] assessed the ability of the coculture of bacteria and fungi to decompose large-cyclic PAHs such as benzo [a] anthracene, dibenzo $[\mathrm{a}, \mathrm{h}]$ anthracene, and benzo [a] pyrene, and the highest degradation rate was for benzo [a] pyrene. Some scholars have concluded that fungi stimulate the initial reaction of large-ring PAHs in the coculture system, and bacteria are mainly responsible for the degradation of metabolites $[108,146,147,161]$. The fundamental reason for promoting the synergistic degradation of PAHs by bacteria and fungi is to improve the bioavailability of pollutants [162]. The synergistic degradation pathway for PAHs in bacteria and fungi is their degradation by P450 monooxygenase and then the production of trans-dihydrodiol in 
fungi, which is further converted into diol products by catalysis of dehydrogenase. Fungi can also mineralize PAHs to PAH-quinone products through lignin-degrading enzymes and degrade quinone products into diol products under the action of $\mathrm{O}$-quinone oxidoreductase secreted by bacteria [163]. The diol products are eventually converted into $\mathrm{CO}_{2}$ and $\mathrm{H}_{2} \mathrm{O}$ catalyzed by other bacterial enzymes involved in degradation.

\section{Conclusions and Future Prospect}

As a class of organic pollutants, which are strictly controlled in terms of soil quality standards, PAHs show strong "three causes and effects" (carcinogenesis, teratogenesis, and mutation). PAHs exert unpredictable toxic effects on the balanced development of soil ecological environment and normal human body functions. Phytomicrobial remediation is environmentally friendly and economical, and provides a new feasible approach for the treatment and control of field pollution and farmland pollution. The development of remediation technologies for PAHs-contaminated soil should not only clarify the various metabolic mechanisms of PAHs degradation and transformation, but also rely on the understanding of ecological pollution under specific soil environmental conditions. The following points are the conclusions, including technical bottlenecks and theoretical gaps that need further consideration and exploration:

(1) A complete evaluation model for the potential risks of PAHs and their metabolites in the soil environment was further developed to provide a theoretical basis for additional management of the remediation of PAHs-contaminated soil.

(2) The metabolic mechanism of PAHs in plants was further explored and improved.

(3) The activity and PAH degradation potential of endophytic bacteria in the plant were further studied to develop a method to enhance the degradation of PAHs.

(4) To provide the theoretical basis for the development of microbial remediation technologies to treat PAHs-contaminated soil, the effects of microbial synergism on PAH degradation were theoretically determined in terms of the conversion pathways, key degradation products, and the rate-limiting enzymes involved.

(5) Most existing remediation technologies are aimed at the remediation of the same PAHscontaminated soil, but, in reality, the pollutants in the contaminated site are more complex and diverse. Therefore, a new research direction was provided to strengthen the remediation effect of plants and microorganisms on PAHs- contaminated soil.

(6) The feasibility of the optimized phytomicrobial remediation technology was compared with that of other remediation technologies to improve the remediation efficiency for contaminated sites.

Author Contributions: Conceptualization, L.Z. and Y.L.; formal analysis, C.L.; investigation, L.Z.; resources, Y.L.; data curation, L.Z.; writing-original draft preparation, L.Z.; writing-review and editing, C.L. and Y.L.; supervision, Y.L. All authors have read and agreed to the published version of the manuscript.

Funding: This research received no external funding.

Institutional Review Board Statement: Not applicable.

Informed Consent Statement: Not applicable.

Data Availability Statement: Not applicable.

Conflicts of Interest: The authors declare no conflict of interest.

\section{References}

1. Zhang, Y. Discussion on Measures for Doing a Good Job in Oil Production Safety Supervision under the New Situation. Chem. Manag. 2019, 15, 218-219.

2. Wei, S.M.; Li, C.Q.; Wang, R.B.; Chang, G.H.; Sun, H.L. Research Status of Petroleum Contaminated Soil Remediation Technology. J. Green Sci. Technol. 2019, 10, 118-119.

3. Kim, S.J.; Park, M.K.; Lee, S.E.; Go, H.J.; Cho, B.C.; Lee, Y.S.; Choi, S.D. Impact of traffic volumes on levels, patterns, and toxicity of polycyclic aromatic hydrocarbons in roadside soils. Environ. Sci. Process. Impacts 2019, 21, 174-182. [CrossRef] [PubMed] 
4. Sweet, L.E.; Revill, A.T.; Strzelecki, J.; Hook, S.E.; Morris, J.M.; Roberts, A.P. Photo-induced toxicity following exposure to crude oil and ultraviolet radiation in 2 Australian fishes. Environ. Toxicol. Chem. 2018, 37, 1359-1366. [CrossRef] [PubMed]

5. Lei, P.; Pan, K.; Zhang, H.; Zhou, Y.Q.; Bi, J.L. A device for the rapid extraction of 16 priority PAHs in aquatic sediments. Environ. Chem. 2019, 38, 494-502.

6. Meng, Y.; Liu, X.H.; Lu, S.Y.; Zhang, T.T.; Jin, B.C.; Wang, Q.; Tang, Z.R.; Liu, Y.; Guo, X.C.; Zhou, J.L.; et al. A review on occurrence and risk of polycyclic aromatic hydrocarbons (PAHs) in lakes of China. Sci. Total Environ. 2019, 651, 2497-2506. [CrossRef]

7. Gu, Y.G.; Ke, C.L.; Liu, Q. Characterization, sources, and ecological hazards of polycyclic aromatic hydrocarbons in the intertidal sediments of Zhelin Bay, the biggest mariculture area on the eastern Guangdong coast of China. Mar. Pollut. Bull. 2018, 130, 192-197. [CrossRef]

8. Lin, G.M.; Wu, J.; Wang, M.; Sha, C.Y.; Huang, S.F.; Gao, F.L.; Zhang, H.L. Analysis of composition and distribution characteristics of polycyclic aromatic hydrocarbons in surrounding soil of petrochemical industrial area. Environ. Pollut. Control 2015, 37, 39-45. (In Chinese)

9. Zhu, L.Y.; Lan, J.C.; Sun, Y.C.; Shen, L.C.; Wang, Z.B.; Ye, K. Distribution characteristics and health risks of PAHs in soils and groundwater in typical Karst areas. Acta Sci. Circumstantiae 2020, 40, 3361-3374. (In Chinese)

10. Wan, H.B.; Zhou, J.; Luo, D.; Yang, H.; Huang, C.C.; Huang, T. Distribution, source characteristics and ecological risk assessment of polycyclic aromatic hydrocarbons in surface sediments of lakes along the middle reaches of the Yangtze River. J. Lake Sci. 2020, 32, 1632-1645. (In Chinese)

11. Yan, D.H.; Wu, S.H.; Zhou, S.L.; Tong, G.J.; Li, F.F.; Wang, Y.M.; Li, B.J. Characteristics, sources and health risk assessment of airborne particulate PAHs in Chinese cities: A review. Environ. Pollut. 2019, 248, 804-814. [CrossRef] [PubMed]

12. Zhang, Y.X.; Chen, H.Y.; Liu, C.; Chen, R.H.; Wang, Y.Y.; Teng, Y.G. Developing an integrated framework for source apportionment and source-specific health risk assessment of PAHs in soils: Application to a typical cold region in China. J. Hazard. Mater. 2021, 415, 125730. [CrossRef]

13. Zhao, C.C.; Xu, J.T.; Shang, D.W.; Zhang, Y.M.; Zhang, J.; Xie, H.J.; Kong, Q.; Wang, Q. Application of constructed wetlands in the PAH remediation of surface water: A review. Sci. Total Environ. 2021, 780, 146605. [CrossRef] [PubMed]

14. Soclo, H.H.; Garrigues, P.; Ewald, M. Origin of Polycyclic Aromatic Hydrocarbons (PAHs) in Coastal Marine Sediments: Case Studies in Cotonou (Benin) and Aquitaine (France) Areas. Mar. Pollut. Bull. 2000, 40, 387-396. [CrossRef]

15. Ma, J. Isolation of PAHs-Degrading Bacteria and Characterization of the Degradation Metabolism. Ph.D. Thesis, Dalian University of Technology, Dalian, China, 2013.

16. Nevenka, B.; Maja, F.; Bojan, H.; Blanka, K.B. PAH content, toxicity and genotoxicity of coastal marine sediments from the Rovinj area, Northern Adriatic, Croatia. Sci. Total Environ. 2006, 366, 602-611.

17. Li, H.L.; Chen, J.J.; Wu, W.; Piao, X.S. Distribution of polycyclic aromatic hydrocarbons in different size fractions of soil from a coke oven plant and its relationship to organic carbon content. J. Hazard. Mater. 2010, 176, 729-734. [CrossRef] [PubMed]

18. Wang, P.; Chen, L.N.; Jiang, P.; Liu, Y. A comparative study of two toxicity evaluation methods on human health risks in a PAHs contaminated site. Asian J. Ecotoxicol. 2016, 11, 180-190. (In Chinese)

19. Kim, K.H.; Jahan, S.A.; Kabir, E.; Brown, R.J.C. A review of airborne polycyclic aromatic hydrocarbons (PAHs) and their human health effects. Environ. Int. 2013, 60, 71-80. [CrossRef]

20. Pulster, E.L.; Gracia, A.; Snyder, S.M.; Murawski, S.A.; Fogelson, S.; Deak, K. Chronic Sublethal Effects Observed in Wild-Caught Fishes Following Two Major Oil Spills in the Gulf of Mexico: Deepwater Horizon and Ixtoc 1. In Deep Oil Spills; Springer: Cham, Switzerland, 2020; pp. 388-413.

21. Pulster, E.L.; Fogelson, S.; Carr, B.E.; Mrowicki, J.; Murawski, S.A. Hepatobiliary PAHs and prevalence of pathological changes in Red Snapper. Aquat. Toxicol. 2021, 230, 105714. [CrossRef] [PubMed]

22. Han, J.; Liang, Y.H.; Zhao, B.; Wang, Y.; Xing, F.T.; Qin, L.B. Polycyclic aromatic hydrocarbon (PAHs) geographical distribution in China and their source, risk assessment analysis. Environ. Pollut. 2019, 251, 312-327. [CrossRef]

23. Wang, J.; Liu, J.; Ling, W.T.; Huang, Q.G.; Gao, Y.Z. Composite of PAH-degrading endophytic bacteria reduces contamination and health risks caused by PAHs in vegetables. Sci. Total Environ. 2017, 598, 471-478. [CrossRef] [PubMed]

24. Hua, X.Y. Spatial Distribution, Source and Ecological Risk Assessment of Polycyclic Aromatic Hydrocarbons in Soil of Northern Songnen Plain. Master's Thesis, Harbin Normal University, Harbin, China, 2017.

25. Bernhard, A.; Bernd, M.B.; Petra, L.H.; Sebastian, H. Regionalized concentrations and fingerprints of polycyclic aromatic hydrocarbons (PAHs) in German forest soils. Environ. Pollut. 2015, 203, 31-39.

26. Qiu, Y.Y.; Gong, Y.X.; Ni, H.G. Contribution of soil erosion to PAHs in surface water in China. Sci. Total Environ. 2019, 686, 497-504. [CrossRef] [PubMed]

27. Bungau, S.; Tit, D.M.; Fodor, K.; Cioca, G.; Agop, M.; Iovan, C.; Cseppento, D.C.N.; Bumbu, A.; Bustea, C. Aspects Regarding the Pharmaceutical Waste Management in Romania. Sustainability 2018, 10, 2788. [CrossRef]

28. Bungau, S.; Bungau, C.; Tit, D.M. Studies on the Last Stage of Product Lifecycle Management for A Pharmaceutical Product. J. Environ. Prot. Ecol. 2015, 16, 56-62.

29. Tang, L.; Tang, X.Y.; Zhu, Y.G.; Zheng, M.H.; Miao, Q.L. Contamination of polycyclic aromatic hydrocarbons (PAHs) in urban soils in Beijing, China. Environ. Int. 2005, 31, 822-828. [CrossRef] [PubMed] 
30. Christopher, H.V.; Alexander, W.K.; Darren, J.B.; Mark, R.C.; Katherine, K.; Vicky, M.H.; Paul, C.N. Polycyclic aromatic hydrocarbons (PAH) and polychlorinated biphenyls (PCB) in urban soils of Greater London, UK. Appl. Geochem. 2014, 51, 303-314.

31. Zhang, P.; Chen, Y.G. Polycyclic aromatic hydrocarbons contamination in surface soil of China: A review. Sci. Total Environ. 2017, 605-606, 1011-1020. [CrossRef]

32. Qu, Y.J.; Gong, Y.W.; Ma, J.; Wei, H.Y.; Liu, Q.Y.; Liu, L.L.; Wu, H.W.; Yang, S.H.; Chen, Y.X. Potential sources, influencing factors, and health risks of polycyclic aromatic hydrocarbons (PAHs in the surface soil of urban parks in Beijing, China. Environ. Pollut. 2020, 260, 114016. [CrossRef]

33. Bungau, S.; Behl, T.; Aleya, L.; Bourgeade, P.; Aloui-Sossé, B.; Purza, A.L.; Abid, A.; Samuel, A.D. Expatiating the impact of anthropogenic aspects and climatic factors on long-term soil monitoring and management. Environ. Sci. Pollut. Res. 2021, 28, 30528-30550. [CrossRef]

34. Samuel1, A.D.; Bungau, S.; Tit, D.M.; Melinte, C.E.; Purza, L.; Badea1, G.E. Effects of Long Term Application of Organic and Mineral Fertilizers on Soil Enzymes. Rev. Chim. Buchar. Orig. Ed. 2018, 69, 2608-2612. [CrossRef]

35. Sarma, H.; Prasad, M.N.V. Plant-microbe association-assisted removal of heavy metals and degradation of polycyclic aromatic hydrocarbons. In Petroleum Geosciences: Indian Contexts; Springer: Cham, Switzerland, 2015; pp. 219-236.

36. Kuppusamy, S.; Thavamani, P.; Venkateswarlu, K.; Lee, Y.B.; Naidu, R.; Megharaj, M. Remediation approaches for polycyclic aromatic hydrocarbons (PAHs) contaminated soils: Technological constraints, emerging trends and future directions. Chemosphere 2017, 168, 944-968. [CrossRef] [PubMed]

37. Kuppusamy, S.; Thavamani, P.; Megharaj, M.; Venkateswarlu, K.; Naidu, R. In-Situ Remediation Approaches for the Management of Contaminated Sites: A Comprehensive Overview. Rev. Environ. Contam. Toxicol. 2016, 236, 1-115.

38. Shi, Y.; Luo, Z.H.; Wang, Y.X.; Cai, M.L.; Yang, L.M. New advances in in-situ thermal desorption technology for contaminated soil. Sci. China Technol. Sci. 2019, 62, 2075-2076. [CrossRef]

39. Wu, W.; Xie, Z.; Xu, J.; Liu, C. Fluoride Emission from Different Soil Minerals at High Temperatures. Environ. Sci. 2001, 22, 106-109. (In Chinese)

40. Lemaire, J.; Buès, M.; Kabeche, T.; Hanna, K.; Simonnot, M.O. Oxidant selection to treat an aged PAH contaminated soil by in situ chemical oxidation. J. Environ. Chem. Eng. 2013, 1, 1261-1268. [CrossRef]

41. Usman, M.; Faure, P.; Ruby, C.; Hanna, K. Application of magnetite-activated persulfate oxidation for the degradation of PAHs in contaminated soils. Chemosphere 2012, 87, 234-240. [CrossRef]

42. Mohan, S.V.; Kisa, T.; Ohkuma, T.; Kanaly, R.A.; Shimizu, Y. Bioremediation technologies for treatment of PAH-contaminated soil and strategies to enhance process efficiency. Rev. Environ. Sci. Bio/Technol. 2006, 5, 347-374. [CrossRef]

43. Baldantoni, D.; Morelli, R.; Bellino, A.; Prati, M.V.; Alfani, A.; De, N.F. Anthracene and benzo(a)pyrene degradation in soil is favoured by compost amendment: Perspectives for a bioremediation approach. J. Hazard. Mater. 2017, 339, 395-400. [CrossRef]

44. Jyotika, P.; Anirudha, C.; Mohan, K.B.; Nirbhay, K.S. Mycoremediation of Agricultural Soil: Bioprospection for Sustainable Development. In Mycoremediation and Environmental Sustainability; Springer International Publishing: Cham, Switzerland, 2018; pp. 91-120.

45. Ma, J.; Zhang, W.Y.; Chen, Y.; Zhang, S.L.; Feng, Q.Y.; Hou, H.P.; Chen, F.; Lin, Y.P. Spatial Variability of PAHs and Microbial Community Structure in Surrounding Surficial Soil of Coal-Fired Power Plants in Xuzhou, China. Int. J. Environ. Res. Public Health 2016, 13, 878. [CrossRef]

46. Bellino, A.; Baldantoni, D.; Picariello, E.; Morelli, R.; Alfani, A.; De, N.F. Role of different microorganisms in remediating PAH-contaminated soils treated with compost or fungi. J. Environ. Manag. 2019, 252, 109675. [CrossRef]

47. Cai, R.T.; Xiao, X.; Dong, Z.B.; Cao, J.J.; Zhang, N.N.; Liu, S.X.; Shen, Z.X.; Xu, H.M.; Tao, Y.; Li, X.M.; et al. Characteristics and health risk of polycyclic aromatic hydrocarbons in PM2.5 in the typical urban and rural areas of the Fenwei Plain. Acta Geogr. Sin. 2021, 76, 740-752. (In Chinese)

48. Roudbari, A.; Nazari, R.R.; Shariatifar, N.; Moazzen, M.; Arabameri, M. Concentration and health risk assessment of polycyclic aromatic hydrocarbons in commercial tea and coffee samples marketed in Iran. Environ. Sci. Pollut. Res. 2021, 28, 4827-4839. [CrossRef]

49. Tiwari, M.; Sahu, S.K.; Rathod, T.D.; Bhangare, R.C.; Kumar, A.V. Measurement of size-fractionated atmospheric particulate matter and associated polycyclic aromatic hydrocarbons in Mumbai, India, and their dry deposition fluxes. Air. Qual. Atmos. Health 2020, 13, 939-949. [CrossRef]

50. Xie, Z.; Yang, J.; Huang, Q.; Yang, Y. Occurrence of heavy metals and polycyclic aromatic hydrocarbons in typical used mineral oil from china: Implications for risk management. Environ. Sci. Pollut. Res. 2020, 27, 33065-33074. [CrossRef] [PubMed]

51. Fan, Y.; Xu, F. Restore Technologies for PAHs Polluted Soil. Build. Technol. 2019, 3, 64-67. (In Chinese)

52. Zhang, H.; Wang, J.; Bao, H.; Li, J.; Wu, F. Polycyclic aromatic hydrocarbons in urban soils of Zhengzhou city, china: Occurrence, source and human health evaluation. Bull. Environ. Contam. Toxicol. 2020, 105, 446-452. [CrossRef]

53. Zhao, N.; Ju, F.; Pan, H.; Tang, Z.; Ling, H. Molecular dynamics simulation of the interaction of water and humic acid in the adsorption of polycyclic aromatic hydrocarbons. Environ. Sci. Pollut. Res. 2020, 27, 25754-25765. [CrossRef] [PubMed]

54. Luo, H.F.; Qiao, Y.D.; Ning, Z.X.; Yang, D.; Cheng, H.M.; Hu, J.G. Study on leaching characteristics of polycyclic aromatic hydrocarbons after filling soil of coal gangue. China Min. Mag. 2021, 30, 151-156. (In Chinese) 
55. Lu, X.L.; Kang, X.; Wei, Y.C.; Wang, F.; Bai, H.R.; Pan, J.J. Spatial Distribution and Sources of PAHs in Farmland Soil of Peri-urban Areas: A Case Study of Zhougang, Nanjing. Chin. J. Soil Sci. 2021, 52, 286-296. (In Chinese)

56. Liu, A.; Gong, J.W.; Han, B.; Zhao, J.; Zheng, L. Analysis of distribution, sources and ecological risks of polycyclic aromatic hydrocarbons in topsoil of fildes peninssula. Chin. J. Polar Sci. 2021, 33, 49-57. (In Chinese)

57. Azimi, A.; Bakhtiari, A.R.; Tauler, R. Polycyclic aromatic hydrocarbon source fingerprints in the environmental samples of anzali-South of caspian sea. Environ. Sci. Pollut. Res. 2020, 27, 32719-32731. [CrossRef]

58. Benlaribi, R.; Djebbar, S. Concentrations, distributions, sources, and risk assessment of polycyclic aromatic hydrocarbons in topsoils around a petrochemical industrial area in algiers. Environ. Sci. Pollut. Res. 2020, 27, 29512-29529. [CrossRef]

59. Ehigbor, M.J.; Iwegbue, C.; Eguavoen, O.I.; Tesi, G.O.; Martincigh, B.S. Occurrence, sources and ecological and human health risks of polycyclic aromatic hydrocarbons in soils from some functional areas of the nigerian megacity, lagos. Environ. Geochem. Health 2020, 42, 2895-2923. [CrossRef]

60. Hu, X.J.; Sun, Y. Oxidation of Industrial Soil Contaminated with Polycyclic Aromatic Hydrocarbons Using Chlorine Dioxide. J. Technol. 2021, 21, 88-91. (In Chinese)

61. Maradny, A.; Eisherbiny, M.; Ghandourah, M.; Ahmed, M.; Orif, M. PAH bioaccumulation in two polluted sites along the eastern coast of the red sea, saudi arabia. Int. J. Environ. Sci. Technol. 2020, 18, 1335-1348. [CrossRef]

62. Evangelia, M.; Athanasios, K.; Olga, K.; Georgios, A.; Dimitra, V.; Constantini, S. Polycycli aromatic hydrocarbons (PAHs) at traffic and urban background sites of northern Greece: Source apportionment of ambient PAH levels and PAH-induced lung cancer risk. Environ. Sci. Pollut. Res. 2015, 23, 3556-3568.

63. Lan, A.; Ngoc, N.T.; Quynh, N.T.; Nguyen, V.T.; Anh, D.H. Polycyclic aromatic hydrocarbons (PAHs) in dry tea leaves and tea infusions in vietnam: Contamination levels and dietary risk assessment. Environ. Geochem. Health 2020, 42, $2853-2863$.

64. Sun, J.; Zhang, Z.T.; Guo, H.J.; Wang, H. Progresses in anaerobic microbial degradation of polycyclic aromatic hydrocarbons. Acta Microbiol. Sin. 2020, 368, 233-250. (In Chinese)

65. Candeniz, S. Extended Exergy Accounting analysis of IGCC process-Determination of environmental remediation cost of refinery and coke processing waste. J. Clean. Prod. 2016, 119, 178-186.

66. Bandowe, B.A.M.; Leimer, S.; Meusel, H.; Velescu, A.; Dassen, S.; Eisenhauer, N.; Hoffmann, T.; Oelmann, Y.; Wilcke, W. Plant diversity enhances the natural attenuation of polycyclic aromatic compounds (PAHs and oxygenated PAHs) in grassland soils. Soil Biol. Biochem. 2019, 129, 60-70. [CrossRef]

67. Sun, Y.B.; Zhou, Q.X. Uptake and translocation of benzo[a]pyrene (B[a]P) in two ornamental plants and dissipation in soil. Ecotoxicol. Environ. Saf. 2016, 124, 74-81. [CrossRef] [PubMed]

68. Maathuis, F.; Sanders, D. Mechanisms of potassium absorption by higher plant roots. Physiol. Plant. 2010, 96, 158-168. [CrossRef]

69. Guo, P.P.; Guo, K.J.; Ren, Y.; Shi, Y.; Chang, J.; Tani, A.; Ge, Y. Biogenic volatile organic compound emissions in relation to plant carbon fixation in a subtropical urban-rural complex. Landsc. Urban Plan. 2013, 119, 74-84. [CrossRef]

70. Raupach, M.R.; Finnigan, J.J. Single-layer models of evaporation from plant canopies are incorrect but useful, whereas multilayer models are correct but useless: Discuss. Funct. Plant Biol. 1988, 15, 705-716. [CrossRef]

71. Ling, Q.; Kudla, U.; Roze, E.; Goverse, A.; Popeijus, H.; Nieuwland, J.; Overmars, H.; Jones, J.T.; Schots, A.; Smant, G.; et al. Plant degradation: A nematode expansin acting on plants. Nature 2004, 427, 30.

72. Posada-Baquero, R.; Jimenez-Volkerink, S.N.; García, J.L.; Vila, J.; Cantos, M.; Grifoll, M.; Ortega-Calvo, J.J. Rhizosphere-enhanced biosurfactant action on slowly desorbing PAHs in contaminated soil. Sci. Total Environ. 2020, 720, 137608. [CrossRef] [PubMed]

73. Rehman, M.; Taqi, M.M.; Hussain, I.; Nasir, J.; Rizvi, S.; Syed, J.H. Elevated exposure to polycyclic aromatic hydrocarbons (PAHs) may trigger cancers in pakistan: An environmental, occupational, and genetic perspective. Environ. Sci. Pollut. Res. 2020, 27, 42405-42423. [CrossRef]

74. Yang, Y. Isolation and Characterization of Phenanthrene-Degrading Bacteria and Their Preliminary Application in Plant-Microbe Combined Remediation of Heavy Metals-Phenanthrene Co-Contaminated Soil. Master's Thesis, Nanjing Agricultural University, Nanjing, China, 2013.

75. Kong, D.K.; Wang, H.Q.; Liu, Z.L.; Xu, J.; Xiong, Y. Remediation of petroleum hydrocarbon contaminated soil by plant-microbe and the change of rhizosphere microenvironment. Asian J. Ecotoxicol. 2017, 12, 644-651. (In Chinese)

76. Song, L.C.; Niu, X.G.; Tian, Y.M.; Xiao, Y.N. Assessment of PAH degradation potential of native species from a coking plant through identifying of the beneficial bacterial community within the rhizosphere soil. Chemosphere 2021, 264, 128513. [CrossRef]

77. Rein, A.; Adam, I.K.U.; Miltner, A.; Brumme, K.; Kästner, M.; Trapp, S. Impact of bacterial activity on turnover of insoluble hydrophobic substrates (phenanthrene and pyrene)-Model simulations for prediction of bioremediation success. J. Hazard. Mater. 2016, 306, 105-114. [CrossRef] [PubMed]

78. Bao, H.Y.; Wang, J.F.; Zhang, H.; Li, J.; Li, H.; Wu, F.Y. Effects of biochar and organic substrates on biodegradation of polycyclic aromatic hydrocarbons and microbial community structure in PAHs-contaminated soils. J. Hazard. Mater. 2020, $385,121595$. [CrossRef] [PubMed]

79. Anyika, C.; Abdul, M.Z.; Ibrahim, Z.; Zakaria, M.P.; Yahya, A. The impact of biochars on sorption and biodegradation of polycyclic aromatic hydrocarbons in soils—a review. Environ. Sci. Pollut. Res. 2015, 22, 3314-3341. [CrossRef] [PubMed]

80. Kong, L.L.; Song, B.P.; Zhang, T.T.; Gao, K.N.; Liu, J.Z. Effects of soil organic matter on biochar application in developing the biodegradation potentials of polycyclic aromatic hydrocarbons (PAHs). Appl. Soil Ecol. 2021, 167, 104046. [CrossRef] 
81. Ameloot, N.; Graber, E.R.; Verheijen, F.G.A.; Neve, S.D. Interactions between biochar stability and soil organisms: Review and research needs. Eur. J. Soil Sci. 2013, 64, 379-390. [CrossRef]

82. Zhang, F.S.; Zhang, G.X.; Liao, X.Y. Negative role of biochars in the dissipation and vegetable uptake of polycyclic aromatic hydrocarbons (PAHs) in an agricultural soil: Cautions for application of biochars to remediate PAHs-contaminated soil. Ecotoxicol. Environ. Saf. 2021, 213, 112075. [CrossRef] [PubMed]

83. Zhang, G.X.; He, L.X.; Guo, X.F.; Han, Z.W.; Ji, L.; He, Q.S.; Han, L.F.; Sun, K. Mechanism of biochar as a biostimulation strategy to remove polycyclic aromatic hydrocarbons from heavily contaminated soil in a coking plant. Geoderma 2020, 375, 114497. [CrossRef]

84. Xie, L.P.; Zhu, C.Z.; Zhang, X.D.; Yu, R.; Zhan, M.J.; Sun, L.W. Preliminary Study on Remediation of PAH-contaminated Soil by Enhanced Biopile. J. Ecol. Rural Environ. 2021, 37, 96-102. (In Chinese)

85. Li, Z.H.; Wang, W.; Zhu, L.Z. Effects of mixed surfactants on the bioaccumulation of polycyclic aromatic hydrocarbons (PAHs) in crops and the bioremediation of contaminated farmlands. Sci. Total Environ. 2019, 646, 1211-1218. [CrossRef]

86. Gu, W.W.; Zhao, Y.Y.; Li, Q.; Li, Y. Plant-microorganism combined remediation of polychlorinated naphthalenes contaminated soils based on molecular directed transformation and taguchi experimental design-assisted dynamics simulation. J. Hazard. Mater. 2020, 396, 122753. [CrossRef]

87. Gu, W.W.; Li, X.X.; Li, Q.; Hou, Y.L.; Zheng, M.S.; Li, Y. Combined Remediation of Polychlorinated Naphthalene-Contaminated Soil under Multiple Scenarios: An Integrated Method of Genetic Engineering and Environmental Remediation Technology. J. Hazard. Mater. 2020, 405, 124139. [CrossRef]

88. Zhou, X.; Zhang, D.R.; Li, P. Application of chemical oxidative remediation technology to PAHs contaminated soil. Environ. Dev. 2020, 163, 99-100. (In Chinese)

89. Qing, X.D.; Zhou, H.B.; Zhang, X.H.; Wu, H.L.; Li, S.S. Alternating trilinear decomposition of highly overlapped chromatograms for simultaneously targeted quantification of 15 PAHs in samples of pollution source. Microchem. J. 2019, 146, 742-752. [CrossRef]

90. Thouron, L.; Seigneur, C.; Kim, Y.; Legorgeu, C.; Bruge, B. Simulation of trace metals and PAH atmospheric pollution over greater paris: Concentrations and deposition on urban surfaces. Atmos. Environ. 2017, 167, 360-376. [CrossRef]

91. Kong, S.F.; Yan, Q.; Zheng, H.; Liu, H.B.; Wang, W.; Zheng, S.R. Substantial reductions in ambient PAHs pollution and lives saved as a co-benefit of effective long-term $\mathrm{PM}_{2.5}$ pollution controls. Environ. Int. 2018, 114, 266-279. [CrossRef] [PubMed]

92. Wen, H.Y.; Liao, Y.Z.; Li, X.D. Research progress in microbial degradation of polycyclic aromatic hydrocarbons. J. Microbiol. 2005, 25, 73-75. (In Chinese)

93. Li, C.Y.; Liu, S.; Sun, N.; Liu, J.; Cai, Z.X.; Yu, S.J. Research progress of PAHs environmental behaviors on soil and sediment. J. Northeast Agric. Univ. 2021, 52, 87-94. (In Chinese)

94. Martorell, I.; Perelló, G.; Martí-Cid, R.; Llobet, J.M.; Castell, V.; Domingo, J.L. Human exposure to arsenic, cadmium, mercury, and lead from foods in Catalonia, Spain: Temporal trend. Biol. Trace Elem. Res. 2011, 142, 309-322. [CrossRef] [PubMed]

95. Fismes, J.; Perrin, G.C.; Empereur, B.P.; Morel, J.L. Soil to root transfer and translocation of polycyclic aromatic hydrocarbons by vegetables grown on industrial contaminated soils. J. Environ. Qual. 2002, 31, 1649-1656. [CrossRef]

96. Camargo, M.C.; Toledo, M.F. Polycyclic aromatic hydrocarbons in Brazilian vegetables and fruits. Food Control 2003, 14, 49-53. [CrossRef]

97. Waqas, M.; Khan, S.; Chao, C.; Shamshad, I.; Qamar, Z.; Khan, K. Quantification of PAHs and health risk via ingestion of vegetable in khyber pakhtunkhwa province, pakistan. Sci. Total Environ. 2014, 497-498, 448-458. [CrossRef]

98. Zhang, X.; Yang, J.; Liu, M.; Chen, X.; Wu, J. Distribution characteristics and source analysis of PAHs in farmland soils along Shanghai traffic artery. China Environ. Sci. 2019, 39, 741-749. (In Chinese)

99. Chen, Y.N.; Zhang, J.Q.; Zhang, F.; Liu, X.P.; Zhou, M. Contamination and health risk assessment of PAHs in farmland soils of the Yinma River Basin, China. Ecotoxicol. Environ. Saf. 2018, 156, 383-390. [CrossRef]

100. Zhang, J.; Zhang, H.W.; Zhang, C.G. Effect of groundwater irrigation on soil PAHs pollution abatement and soil microbial characteristics: A case study in Northeast China. Pedosphere 2010, 20, 557-567. [CrossRef]

101. Sushkova, S.; Minkina, T.; Deryabkina, I.; Rajput, V.; Antonenko, E.; Nazarenko, O.; Yadav, B.K.; Hakki, E.; Mohan, D. Environmental pollution of soil with PAHs in energy producing plants zone. Sci. Total Environ. 2019, 655, 232-241. [CrossRef] [PubMed]

102. Zhang, J.M.; Yang, L.X.; Ledoux, F.; Courcot, D.; Mellouki, A.; Gao, Y.; Jiang, P.; Li, Y.Y.; Wang, W.X. PM (2.5)-bound polycyclic aromatic hydrocarbons (PAHs) and nitrated PAHs (NPAHs) in rural and suburban areas in Shandong and Henan provinces during the 2016 Chinese New Year's holiday. Environ. Pollut. 2019, 250, 782-791. [CrossRef] [PubMed]

103. Shi, W.; Guo, Y.J.; Ning, G.H.; Li, C.; Li, Y.; Ren, Y.L.; Zhao, O.Y.; Yang, Z.X. Remediation of soil polluted with HMW-PAHs by alfalfa or brome in combination with fungi and starch. J. Hazard. Mater. 2018, 360, 115-121. [CrossRef] [PubMed]

104. Shen, R.R.; Wang, Y.S.; Gao, W.K.; Cong, X.G.; Cheng, L.L.; Li, X.R. Size-segregated particulate matter bound polycyclic aromatic hydrocarbons (PAHs) over China: Size distribution, characteristics and health risk assessment. Sci. Total Environ. 2019, 685, 116-123. [CrossRef] [PubMed]

105. Tu, Y.T.; Ou, J.H.; Tsang, D.C.W.; Dong, C.D.; Chen, C.W.; Kao, C.M. Source identification and ecological impact evaluation of PAHs in urban river sediments: A case study in Taiwan. Chemosphere 2018, 194, 666-674. [CrossRef] [PubMed]

106. Zeng, S.Y.; Ma, J.; Yang, Y.J.; Zhang, S.L.; Liu, G.J.; Chen, F. Spatial assessment of farmland soil pollution and its potential human health risks in China. Sci. Total Environ. 2019, 687, 642-653. [CrossRef] 
107. Waqas, M.; Khan, S.; Qing, H.; Reid, B.J.; Chao, C. The effects of sewage sludge and sewage sludge biochar on PAHs and potentially toxic element bioaccumulation in Cucumis sativa L. Chemosphere 2014, 105, 53-61. [CrossRef] [PubMed]

108. Crampon, M.; Bureau, F.; Vinceslas, A.M.; Bodilis, J.; Machour, N.; Derf, F.L. Correlations between PAH bioavailability, degrading bacteria, and soil characteristics during PAH biodegradation in five diffusely contaminated dissimilar soils. Environ. Sci. Pollut. Res. 2014, 21, 8133-8145. [CrossRef]

109. Li, Y.H.; Zhao, L.; Chen, F.; Jin, K.S.; Chen, L. Oxidation of nine petroleum hydrocarbon compounds by combined hydrogen peroxide/sodium persulfate catalyzed by siderite. Environ. Sci. Pollut. Res. 2020, 27, 25655-25663. [CrossRef]

110. Naeem, U.; Qazi, M.A. Leading edges in bioremediation technologies for removal of petroleum hydrocarbons. Environ. Sci. Pollut. Res. 2019, 27, 27370-27382. [CrossRef] [PubMed]

111. Frapiccini, E.; Annibaldi, A.; Betti, M.; Polidori, P.; Truzzi, C.; Marini, M. Polycyclic aromatic hydrocarbon (PAH) accumulation in different common sole (solea) tissues from the north Adriatic Sea peculiar impacted area. Mar. Pollut. Bull. 2018, 137, 61-68. [CrossRef] [PubMed]

112. Juma, R.R.; Salum, N.S.; Tairova, Z.; Strand, J.; Bakari, S.S.; Sheikh, M.A. Potential of periophthalmus sobrinus and siganus sutor as bioindicator fish species for PAH pollution in tropical waters. Reg. Stud. Mar. Sci. 2018, 18, 170-176. [CrossRef]

113. Zhang, J.; Liu, Y.S.; Shao, L.D.; Zhang, Z.Z. Isolation and characteristics of PAHs-degrading strains. Chin. J. Appl. Ecol. 2003, 14, 1783-1786. (In Chinese)

114. Liu, F.; Liang, J.S.; Sun, Y.; Guo, Y.B.; Li, Q.X.; Li, J. Isolation and Degradation Characteristics of a HMW PAHs-Degrading Strain LD29. Environ. Sci. 2011, 06, 1799-1804. (In Chinese)

115. Bianco, F.; Monteverde, G.; Race, M.; Papirio, S.; Esposito, G. Comparing performances, costs and energy balance of ex situ remediation processes for PAH-contaminated marine sediments. Environ. Sci. Pollut. Res. 2020, 27, 19363-19374. [CrossRef]

116. Xiao, N.; Liu, R.; Jin, C.X.; Dai, Y.Y. Efficiency of five ornamental plant species in the phytoremediation of polycyclic aromatic hydrocarbon (PAH)-contaminated soil. Ecol. Eng. 2015, 75, 384-391. [CrossRef]

117. Wang, H.; Li, H.B. Study on In Situ Bioremediation of Polycyclic Aromatic Hydrocarbon Contaminated Farmland Soil. Adv. Mat. Res. 2013, 610-613, 1359-1363. [CrossRef]

118. Lu, S.K. A Mathematical Model for Hydrophobic Organic Contaminant Uptake by Plant Roots: A Case Study with Polycyclic Aromatic Hydrocarbons. Master's Thesis, Nanjing Agricultural University, Nanjing, China, 2016. (In Chinese).

119. Kamran, M.A.; Amna; Mufti, R.; Mubariz, N.; Syed, J.H.; Bano, A.; Javed, M.T.; Munis, M.F.H.; Tan, Z.Y.; Chaudhary, H.J. The potential of the flora from different regions of Pakistan in phytoremediation: A review. Environ. Sci. Pollut. Res. 2014, $21,801-812$. [CrossRef]

120. Steliga, T.; Kluk, D. Application of Festuca arundinacea in phytoremediation of soils contaminated with $\mathrm{Pb}, \mathrm{Ni}, \mathrm{Cd}$ and petroleum hydrocarbons. Ecotoxicol. Environ. Saf. 2020, 194, 110409. [CrossRef]

121. Xu, C.B.; Yang, W.J.; Wei, L.S.; Huang, Z.Y.; Wei, W.X.; Lin, A.J. Enhanced phytoremediation of PAHs-contaminated soil from an industrial relocation site by Ochrobactrum sp. Environ. Sci. Pollut. Res. 2020, 27, 8991-8999. [CrossRef]

122. Pang, S.; Duan, L.S.; Liu, Z.Q.; Song, X.Y.; Li, X.F.; Wang, C.J. Co-Induction of a Glutathione-S-transferase, a Glutathione Transporter and an ABC Transporter in Maize by Xenobiotics. PLoS ONE 2012, 7, e40712. [CrossRef]

123. Fujioka, S.; Sakurai, A. Biosynthesis and metabolism of brassinosteroids. Physiol. Plant. 2010, 100, 710-715. [CrossRef]

124. Gworek, B.; Klimczak, K.; Kijeńska, M.; Gozdowski, D. Comparison of PAHs uptake by selected Monocotyledones and Dicotyledones from municipal and industrial sewage sludge. Environ. Sci. Pollut. Res. 2016, 23, 19461-19470. [CrossRef] [PubMed]

125. Yang, L.J.; Yuan, X.; Pan, S.W.; Wu, Y.X. Multispecies Phytoremediation on Degradation of PAHs in Soils. Appl. Mech. Mater. 2014, 522-524, 745-751. [CrossRef]

126. Li, W.M.; Zhang, Z.; Sun, B.; Hu, S.J.; Wang, D.S.; Hu, F.; Li, H.X.; Xu, L.; Jiao, J.G. Combination of plant-growth-promoting and fluoranthene-degrading microbes enhances phytoremediation efficiency in the ryegrass rhizosphere. Environ. Sci. Pollut. Res. 2021, 28, 6068-6077. [CrossRef] [PubMed]

127. Mei, P.; Li, S.J.; Li, Z.B.; Chen, W. Root Exudates and Their Role in Phytoremediation of Contaminated Soils. Environ. Prot. Oil Gas Fields 2017, 27, 1-5. (In Chinese)

128. Hou, L.Q.; Liu, R.; Li, N.; Dai, Y.Y.; Yan, J. Study on the efficiency of phytoremediation of soils heavily polluted with PAHs in petroleum-contaminated sites by microorganism. Environ. Sci. Pollut. Res. 2019, 26, 31401-31413. [CrossRef]

129. Bertin, C.; Yang, X.; Weston, L.A. The role of root exudates and allelochemicals in the rhizosphere. Plant Soil 2003, $256,67-83$. [CrossRef]

130. Sauvadet, M.; Fanin, N.; Chauvat, M.; Bertrand, I. Can the comparison of above- and below-ground litter decomposition improve our understanding of bacterial and fungal successions? Soil Biol. Biochem. 2019, 132, 24-27. [CrossRef]

131. Cristaldi, A.; Conti, G.O.; Jho, E.H.; Zuccarello, P.; Grasso, A.; Copat, C.; Ferrante, M. Phytoremediation of contaminated soils by heavy metals and PAHs. A brief review. Environ. Technol. Innov. 2017, 8, 309-326. [CrossRef]

132. Ding, K.Q.; Luo, Y.M.; Liu, S.L.; Song, J.; Wu, L.H.; Xing, W.Q.; Li, Z.G. Dynamics in benzo[a] pyrene concentrations in soil as influenced by ryegrass plants. Acta Pedol. Sin. 2004, 41, 348-353. (In Chinese)

133. Chaudhry, Q.; Blom-Zandstra, M.; Gupta, S.K.; Joner, E. Utilizing the Synergy between Plants and Rhizosphere Microorganisms to Enhance Breakdown of Organic Pollutants in the Environment (15 pp). Environ. Sci. Pollut. Res. 2005, 12, 34-48. [CrossRef] 
134. Kim, Y.B.; Park, K.Y.; Chung, Y.; Oh, K.C.; Buchanan, B.B. Phytoremediation of Anthracene Contaminated Soils by Different Plant Species. J. Plant Biol. 2004, 47, 174-178. [CrossRef]

135. Elyamine, A.M.; Hu, C. Earthworms and rice straw enhanced soil bacterial diversity and promoted the degradation of phenanthrene. Environ. Sci. Eur. 2020, 32, 1-12. [CrossRef]

136. Liu, X.N.; Li, B.; Tang, C.; Wu, X.Y.; Zhou, J.; Jia, H.H.; Yong, X.Y. Research progresses in microbial degradation of naphthalene. Chin. J. Bioprocess Eng. 2019, 17, 581-589. (In Chinese)

137. Szczepaniak, Z.; Czarny, J.; Staninska-Pieta, J.; Lisiecki, P.; Zgoła-Grześkowiak, A.; Cyplik, P.; Chrzanowski, Ł.; Wolko, Ł.; Marecik, R.; Juzwa, W.; et al. Influence of soil contamination with PAH on microbial community dynamics and expression level of genes responsible for biodegradation of PAH and production of rhamnolipids. Environ. Sci. Pollut. Res. 2016, 23, 23043-23056. [CrossRef]

138. Gan, S.; Lau, E.V.; Ng, H.K. Remediation of soils contaminated with polycyclic aromatic hydrocarbons (PAHs). J. Hazard. Mater. 2009, 172, 532-549. [CrossRef]

139. Yuan, S.; Chang, B.V. Anaerobic degradation of five polycyclic aromatic hydrocarbons from river sediment in Taiwan. J. Environ. Sci. Health Part B 2007, 42, 63-69. [CrossRef]

140. Radzi, N.A.S.M.; Tay, K.S.; Bakar, N.K.A.; Emenike, C.U.; Krishnan, S.; Hamid, F.S.; Abas, M.R. Degradation of polycyclic aromatic hydrocarbons (pyrene and fluoranthene) by bacterial consortium isolated from contaminated road side soil and soil termite fungal comb. Environ. Earth Sci 2015, 74, 5383-5391. [CrossRef]

141. Boll, M.; Estelmann, S. Catabolic Pathways and Enzymes Involved in the Anaerobic Degradation of Polycyclic Aromatic Hydrocarbons. In Anaerobic Utilization of Hydrocarbons, Oils, and Lipid; Springer: Berlin/Heidelberg, Germany, 2020; pp. 135-150.

142. Ambrosoli, R.; Petruzzelli, L.; Minati, J.L.; Marsan, F.A. Anaerobic PAH degradation in soil by a mixed bacterial consortium under denitrifying conditions. Chemosphere 2005, 60, 1231-1236. [CrossRef]

143. Sun, M.M.; Teng, Y.; Luo, Y.M. Progresses in anaerobic biodegradation of polycyclic aromatic hydrocarbons-A review. Acta Microbiol. Sin. 2012, 52, 931-939. (In Chinese)

144. Zhang, X.M.; Young, L.Y. Carboxylation as an Initial Reaction in the Anaerobic Metabolism of Naphthalene and Phenanthrene by Sulfidogenic Consortia. Appl. Environ. Microb. 1998, 63, 4759-4764. [CrossRef]

145. Safinowski, M.; Meckenstock, R.U. Methylation is the initial reaction in anaerobic naphthalene degradation by a sulfate-reducing enrichment culture. Environ. Microbiol. 2010, 8, 347-352. [CrossRef]

146. Musat, F.; Galushko, A.; Jacob, J.; Widdel, F.; Kube, M.; Reinhardt, R.; Wilkes, H.; Schink, B.; Rabus, R. Anaerobic degradation of naphthalene and 2-methylnaphthalene by strains of marine sulfate-reducing bacteria. Environ. Microbiol. 2010, 11, 209-219. [CrossRef] [PubMed]

147. Gupta, S.; Pathak, B.; Fulekar, M.H. Molecular approaches for biodegradation of polycyclic aromatic hydrocarbon compounds: A review. Rev. Environ. Sci. Bio/Technol. 2015, 14, 241-269. [CrossRef]

148. Tsai, J.C.; Kumar, M.; Lin, J.G. Anaerobic biotransformation of fluorene and phenanthrene by sulfate-reducing bacteria and identification of biotransformation pathway. J. Hazard. Mater. 2009, 164, 847-855. [CrossRef] [PubMed]

149. Mu, J.; Leng, Q.L.; Yang, G.F.; Zhu, B.K. Anaerobic degradation of high-concentration polycyclic aromatic hydrocarbons (PAHs) in seawater sediments. Mar. Pollut. Bull. 2021, 167, 112294. [CrossRef]

150. Ite, A.E.; Ibok, U.J. Role of Plants and Microbes in Bioremediation of Petroleum Hydrocarbons Contaminated Soils. Int. J. Environ. Bioremed. Biodegrad 2019, 7, 1-19.

151. Guo, Y.T.; Rene, E.R.; Wang, J.J.; Ma, W.F. Biodegradation of polyaromatic hydrocarbons and the influence of environmental factors during the co-composting of sewage sludge and green forest waste. Bioresour. Technol. 2019, 297, 122434. [CrossRef]

152. Al-Turki, A.I. Microbial Polycyclic Aromatic Hydrocarbons Degradation in Soil. Res. J. Environ. Toxicol. 2009, 3, 1-8. [CrossRef]

153. Acevedo, F.; Pizzul, L.; Castillo, M.D.P.; Cuevas, R.; Diez, M.C. Degradation of polycyclic aromatic hydrocarbons by the Chilean white-rot fungus Anthracophyllum discolor. J. Hazard. Mater. 2010, 185, 212-219. [CrossRef] [PubMed]

154. Asgher, M.; Bhatti, H.N.; Ashraf, M.; Legge, R.L. Recent developments in biodegradation of industrial pollutants by white rot fungi and their enzyme system. Biodegradation 2008, 19, 771-783. [CrossRef] [PubMed]

155. Peng, R.H.; Xiong, A.S.; Xue, Y.; Fu, X.Y.; Gao, F.; Zhao, W.; Tian, Y.S.; Yao, Q.H. Microbial biodegradation of polyaromatic hydrocarbons. FEMS Microbiol. Rev. 2010, 32, 927-955. [CrossRef]

156. Kim, S.J.; Kweon, O.; Jones, R.C.; Edmondson, R.D.; Cerniglia, C.E. Genomic analysis of polycyclic aromatic hydrocarbon degradation in Mycobacterium vanbaalenii PYR-1. Biodegradation 2008, 19, 859-881. [CrossRef]

157. Ghosal, D.; Ghosh, S.; Dutta, T.K.; Ahn, Y. Current State of Knowledge in Microbial Degradation of Polycyclic Aromatic Hydrocarbons (PAHs): A Review. Front. Microbiol. 2016, 7, 1369. [CrossRef]

158. Li, X.J.; Lin, X.; Li, P.J.; Liu, W.; Wang, L.; Ma, F.; Chukwuka, K.S. Biodegradation of the low concentration of polycyclic aromatic hydrocarbons in soil by microbial consortium during incubation. J. Hazard. Mater. 2009, 172, 601-605. [CrossRef]

159. Kotterman, M.; Vis, E.H.; Field, J.A. Successive mineralization and detoxification of benzo[a]pyrene by the white rot fungus Bjerkandera sp. strain BOS55 and indigenous microflora. Appl. Environ. Microb. 1998, 64, 2853-2858. [CrossRef] [PubMed]

160. Boonchan, S.; Britz, M.L.; Stanley, G.A. Degradation and mineralization of high-molecular-weight polycyclic aromatic hydrocarbons by defined fungal-bacterial cocultures. Appl. Environ. Microb. 2000, 66, 1007-1019. [CrossRef] [PubMed]

161. Zhang, Y.P.; Wang, F.; Yang, X.L.; Gu, C.G.; Li, J.; Jiang, X. Recent Advances in Biodegradation of High-molecular Weight PAHs in Soil. Microbiol. China 2010, 37, 280-288. (In Chinese) 
162. Gupta, S.; Pathak, B. Bioremediation of Polycyclic Aromatic Hydrocarbons (PAHs): An Overview. In Abatement of Environmental Pollutants, 6th ed.; Singh, P., Kumar, A., Borthakur, A., Eds.; Elsevier: Amsterdam, The Netherlands, 2019; Volume 6, pp. 127-149.

163. Kim, Y.H.; Engesser, K.H.; Cerniglia, C.E. Two polycyclic aromatic hydrocarbon o-quinone reductases from a pyrene-degrading Mycobacterium. Arch. Biochem. Biophys. 2003, 416, 209-217. [CrossRef] 